\title{
Plant reproductive structures and other mesofossils from Coniacian/Santonian of Lower Silesia, Poland
}

\author{
Zuzana Heřmanová, Jiří Kvaček, Jiřina Dašková, and Adam T. Halamski
}

\begin{abstract}
Mesofossils from the Upper Cretaceous of Lower Silesia are described from the Nowogrodziec Member of the Czerna Formation. The investigated strata are part of the North Sudetic Synclinorium and are of either late Coniacian or early Santonian age. The flora comprises megaspores of lycophytes, conifer and angiosperm mesofossils, and insect-related fossils (coprolite, eggs). Megaspores are assigned to the genus Ricinospora. Fragments of the sterile conifer twigs Cunninghamites sp. and Geinitzia formosa are associated with isolated seeds of the conifer genera Seletya and Alapaja. The greatest diversity is found among reproductive structures of angiosperms within the Normapolles complex. They are assigned to Caryanthus communis, Caryanthus trebecensis, Caryanthus triasseris, Caryanthus sp., Zlivifructus vachae, and Zlivifructus microtriasseris. Additionally, there are several unidentified reproductive structures showing affinities with plants of the Normapolles complex. Finally, there is a single insect coprolite and a few possible insect eggs assigned to Costatheca striata.
\end{abstract}

Zuzana Heřmanová. National Museum, Václavské náměstí 68, Praha 1, Czechia.

zuzka.hermanova@gmail.com

Jiří Kvaček. National Museum, Václavské náměstí 68, Praha 1, Czechia. jiri.kvacek@nm.cz

Jiřina Dašková. National Museum, Václavské náměstí 68, Praha 1, Czechia and The Czech Academy of Sciences, Institute of Geology, Rozvojová 269, Praha 6, Czechia. jirina.daskova@nm.cz

Adam T. Halamski. Institute of Paleobiology, Polish Academy of Sciences, Twarda 51/55, 00-818

Warszawa, Poland. ath@twarda.pan.pl

Key words: Late Cretaceous; Poland; mesofossils; Normapolles complex

Submission: 31 May 2020. Acceptance: 25 November 2020.

Heřmanová, Zuzana, Kvaček, Jiří, Dašková, Jiřina, and Halamski, Adam T. 2020. Plant reproductive structures and other mesofossils from Coniacian/Santonian of Lower Silesia, Poland. Palaeontologia Electronica, 23(3):a61. https://doi.org/10.26879/1097

palaeo-electronica.org/content/2020/3247-mesofossils-of-lower-silesia

Copyright: December 2020 Paleontological Society.

This is an open access article distributed under the terms of Attribution-NonCommercial-ShareAlike 4.0 International (CC BY-NC-SA

4.0 ), which permits users to copy and redistribute the material in any medium or format, provided it is not used for commercial

purposes and the original author and source are credited, with indications if any changes are made.

creativecommons.org/licenses/by-nc-sa/4.0/ 


\section{INTRODUCTION}

Mesofossils related to the Late Cretaceous vegetation of Lower Silesia (south-western Poland; Figure 1) are investigated in this study both as interesting study object in themselves and as a proxy for vegetation reconstruction. A previous study providing an overview of megafossils and palynospectra has been prepared by some of the present authors (Halamski et al., 2020). The paper by Halamski et al. (2020) deals with the mega- and the microflora, whereas mesofossil data are summarized there only as a part of a more extensive palaeoecological analysis of several assemblages (Turonian to middle Santonian). The focus of the present paper is on the systematic description of mesofossils, not given in Halamski et al. (2020).

The present study is a continuation of our interest in fossil plant material from Lower Silesia (Heřmanová et al., 2019). The studied mesofossils expand our understanding of the plant fossil diver- sity, particularly angiosperms of the Normapolles Complex. The diversity of this group is reflected in previously-published dispersed palynospectra from the same area and stratigraphic level (Halamski et al., 2020). The mesofossil material described in the present paper comes from two sources, "old" material stored for several decades in museum collections on the one hand and the material newly collected in the field on the other hand. The "old" material comes only from Rakowice Małe locality (Knobloch and Mai, 1986). The "new" material, collected in 2017-2019, comes from two localities: Rakowice Małe and Żeliszów. We assume that the material collected recently at Rakowice Małe is from approximately the same place where it was collected in the 1980s by Knobloch and Mai (1986).

Fossil reproductive structures from the Rakowice Małe and Żeliszów localities are mostly fruits assigned to the Normapolles complex. The Normapolles complex includes flowers and young or fully developed fruits associated with pollen grains

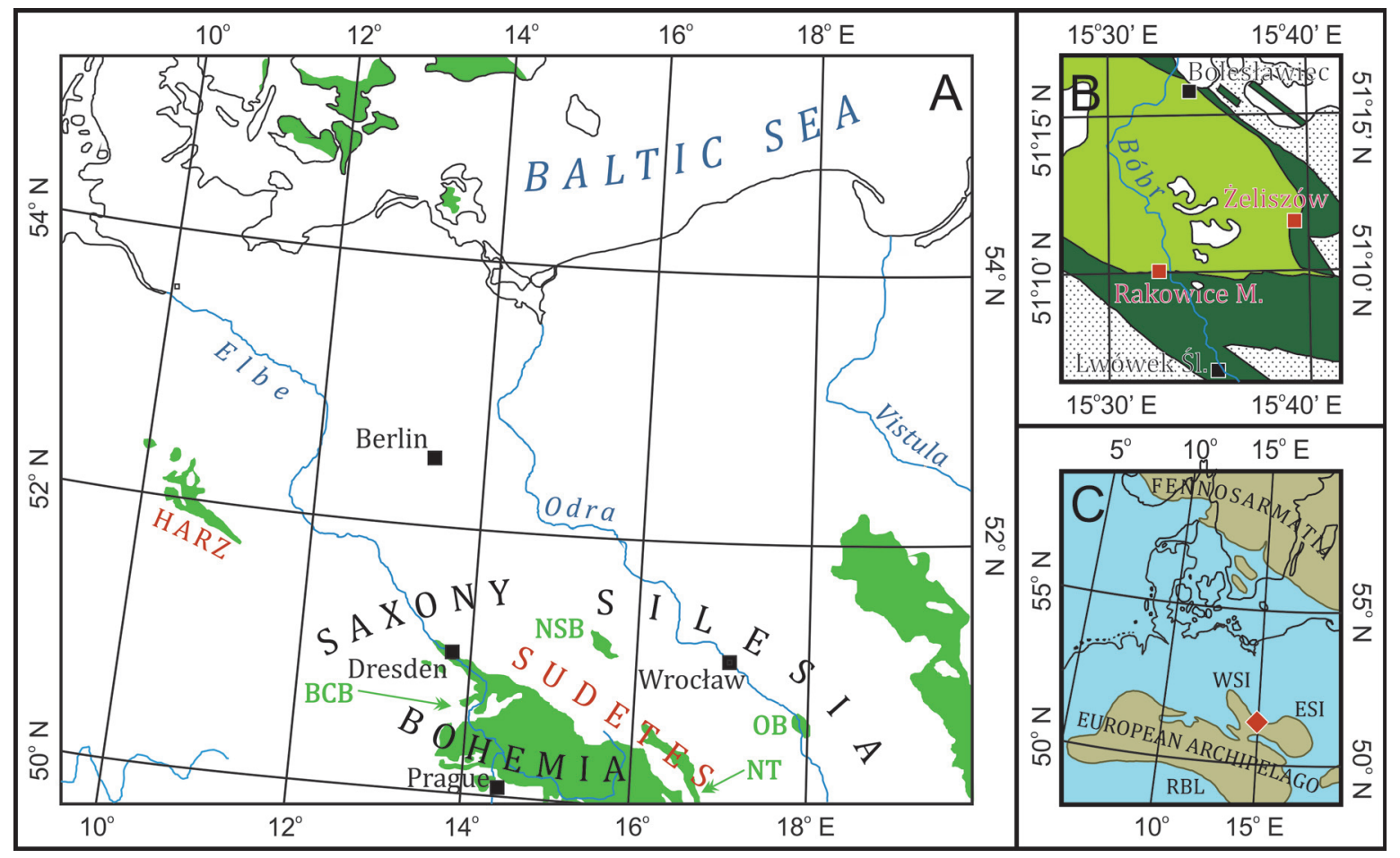

FIGURE 1. Geographic and geologic context of the studied mesoflora. A. Extent of Cretaceous outcrops in Central Europe modified after von Gaertner and Walther (1971). Geographic regions in black typeface, mountains in red, waters in blue, geologic units with Cretaceous sediments in green. BCB, Bohemian Cretaceous basin; NSB, North Sudetic Basin; NT, Nysa Trough; OB, Opole Basin. B. Simplified geologic map of the North Sudetic Basin with main towns (black) and the two outcrops with mesoflora (red). Pre-Cretaceous stippled; Cenomanian to lower-middle Coniacian in dark green; upper Coniacian? to Santonian (Czerna Formation) in light green; post-Cretaceous white. C. Palaeogeography of Central Europe in the Late Cretaceous compared to the present geographic setting after Ron Blakey from Csiki-Sava et al. (2015), modified after data in Chatziemmanouil (1982), Surlyk in Voigt et al. (2008) Janetschke and Wilmsen (2014), and Halamski et al. (2016). ESI, East Sudetic Island; RBL, Rhenish-Bohemian Land; WSI, West Sudetic Island. 
characterized by the presence of a short polar axis and three complex apertures with three germinals (Pflug, 1953). Currently the Normapolles complex comprises about 160 species (Góczán et al., 1967; Batten, 1981; Batten and Christopher, 1981; Pacltová, 1981; Polette and Batten, 2017) and the following "flower" genera: Antiquocarya Friis, Bedellia Sims, Herendeen, Lupia, Christopher et Crane, Budvaricarpus Knobloch et Mai, Calathiocarpus Knobloch et Mai, Caryanthus Friis, Dahlgrenianthus Friis, Pedersen et Schönenberger, Endressianthus Friis, Pedersen et Schönenberger, Manningia Friis and Normanthus Schönenberger, Pedersen et Friis, Zlivifructus Heřmanová, Dašková et J. Kvaček (Friis, 1983; Friis et al., 2003, 2006, 2011; Knobloch and Mai, 1986; Schönenberger et al., 2001; Sims et al., 1999).

The present paper is based on micro-CT, a relatively new technology, which allowed a detailed description and in some cases a reinterpretation of the "old" material. Standard observation under a scanning electron microscope was used first, then, the fossils were further investigated using Microcomputed tomography (micro-CT). Micro-CT uses $\mathrm{X}$-rays to visualize internal structures and provides $3 \mathrm{D}$ reconstructions of the studied fossils. The main benefit of this method is its non-destructive nature. This method allows the study of the internal structures without damaging the specimen and at the same time retains the possibility of a complete repetition of the procedure.

\section{MATERIAL AND METHODS}

The "old" material from the Rakowice Małe locality is a part of Ervín Knobloch's collection gathered in the 1980s, partly published by Knobloch (1984) and Knobloch and Mai (1986). The "new" material was collected in Rakowice Małe and Żeliszów during the 2017 and 2019 field seasons, by two of the authors (JK and ATH).

Ervín Knobloch's collection is housed in the National Museum Prague (NMP), and encompasses megaspores, flowers, fruits, seeds, insect eggs, and coprolites from Lower Silesia and other regions. The greater part of that material was sieved about 50 years ago but never published. In the collections of the National Museum Prague, there were several small boxes labelled "Rakowice Małe - nicht bearbeitet", meaning "not described". This particular part of the collection is described in the present paper.

All studied specimens (from both old and new collections) are charcoalified or lignified mesofossils, gathered using standard bulk maceration. The mesofossil material was treated with hydrofluoric acid and hydrochloric acid, rinsed in water, and dried in air. Preliminary studies were carried out using an Olympus SZX 12 binocular microscope. Specimens for SEM observations were mounted on aluminum stubs using nail polish, coated with gold and studied using a Hitachi S3700 field emission scanning electron microscope at $2 \mathrm{kV}$. Uncoated specimens were studied in low vacuum at $15 \mathrm{kV}$.

Specimens NMP K2768, K2905, K2906 and K2951 were studied using X-ray micro-tomography with the SkyScan 1172 equipment (Bruker). The effective pixel size was ca. $0.5 \mu \mathrm{m}$. Tube voltage was set to $40 \mathrm{kV}$, and the current source was 250 $\mu \mathrm{A}$. No filter was used. The acquired data were processed using flat field correction and reconstructed by the supplied software NRecon (Bruker). Photographs were created by Avizo 9.1 software. The presented figures were edited in Adobe Photoshop CS5. Plates were formed using Adobe InDesign CS5.5.

Under the "Range" we understand the stratigraphic range of the material described in the paper, not the total range of the species.

\section{GEOLOGY}

The mesofossils described in the present paper from the Rakowice Małe and Żeliszów localities were collected in Lower Silesia (Dolny Śląsk, Niederschlesien), more precisely, in the North Sudetic Synclinorium (Walaszczyk, 2008), situated approximately between the towns of Lwówek Śląski (Löwenberg in Schlesien) and Bolesławiec (Bunzlau) in south-western Poland (Figure 1). They all come from a single stratigraphic unit, the formal name of which is the Nowogrodziec Member of the Czerna Formation, which is a characteristic coalyclayey decametre-scale intercalation between two predominantly sandstone parts of the succession. The Nowogrodziec Mb. is a regressive unit. Its deposition took place in an embayment subject to limited marine influence, as testified by the palynomorph assemblage dominated by terrestrial pollen and spores, with only relatively few dinocysts (Halamski et al., 2020).

The "new" mesofossils material was collected from the only two outcrops of the Nowogrodziec Member existing at present. These are the Rakowiczki mine at Rakowice Małe (Wenig-Rackwitz) (several levels with mesoflora within sections RK-2 at $51^{\circ} 9.967^{\prime} \mathrm{N} 15^{\circ} 32.482^{\prime} \mathrm{E}$ and RK-4 at $51^{\circ} 9.962^{\prime} \mathrm{N}$ $\left.15^{\circ} 32.525^{\prime} \mathrm{E}\right)$ and an open-cast mine east from Żeliszów (Giersdorf), where a single mesoflora- 
yielding level was found in a trench dug at $51^{\circ} 11.049^{\prime} \mathrm{N} 15^{\circ} 38.892^{\prime} \mathrm{E}$ (Halamski et al., 2020). A detailed sedimentological account of the Rakowiczki site was given by Leszczyński (2010), whereas the outcrop of the Nowogrodziec Mb. at Żeliszów was discovered only recently (Halamski et al., 2018) and as yet has no comprehensive interpretation. Notable variations in thickness and lithological details are evident both between and within the two outcrops. For example, Halamski et al. (2020, figure 20) observed marine-influenced levels alternating with levels devoid of marine palynomorphs, whereas a section in the same quarry described by Leszczyński, (2010, fig. 4) was interpreted in terms of a general transgressive trend (first a lake, then a lagoon, finally shoreface).

The age of the Nowogrodziec Member is close to the Coniacian-Santonian boundary. It was dated to the early Santonian by Mitura et al. (1969) and Milewicz (1997), but according to Walaszczyk (2008) and Leszczyński (2010), it should be rather treated as late Coniacian, but details have not been provided. Palynological data (Halamski et al., 2020) are inconclusive, but indicative, if anything, rather of the Santonian than the Coniacian.

\section{SYSTEMATIC PALAEONTOLOGY}

\author{
Kingdom PLANTAE Linné, 1753 sensu Cavalier- \\ Smith, 1981 \\ Division LYCOPHYTA Zimmermann, 1959 \\ Class LYCOPODIOPSIDA Bartling, 1830 \\ Order SELAGINELLALES Prantl, 1874 \\ Genus RICINOSPORA Bergad, 1978 emend. Li et \\ al., 1987
}

Type species. Ricinospora cryptoreticulata (Bergad, 1978), pp. 48, 50, pls. 4, 5.

Remarks. The studied material shows a diagnostic character of the genus Ricinospora: the apical spongiose wall sculpturing typical for this genus (Bergad, 1978) in which it differs from similar megaspores.

\section{Ricinospora sp. \\ Figure 2A-C}

v 1984b aff. Istisporites inornatus (Miner) Potonié; Knobloch, p. 172

Description. Trilete megaspore, $400-530 \mu \mathrm{m}$ in diameter, flattened in lateral direction, protruding $Y$ mark, reaching one-third of proximal side (Figure $2 \mathrm{~B}, 2 \mathrm{C}$ ), body of spore delicately reticulate with low muri, polygonal lumina ca $10 \mu \mathrm{m}$. Exoexine reticulate, on the proximal face covered with complex three-dimensional network of exinal strands arising from muri. Sometimes complex spongiose material covers nearly whole megaspore (Figure $2 \mathrm{C}$ ).

Remarks. The studied megaspores were identified by Knobloch (1984) as aff. Istisporites inornatus (Miner) Potonié. The material is mentioned in his review of mid-European Cretaceous megaspores. However, the complex spongiose material is much more characteristic for the genus Ricinospora. The type $R$. cryptoreticulata Bergad (1978) described from the Maastrichtian of North Dakota, USA, is of similar size, the trilete body is also round and the surface is reticulate, it also shows similar spongiose material on the surface (Bergad, 1978). Our material differs in the presence of reticulum with larger lumina and more pronounced muri. Ricinospora sp. differs from $R$. laevigata Li et al. (Li et al., 1987): Ricinospora $\mathrm{sp}$. has delicately reticulate body that can be completely covered by spongiose material, while $R$. laevigata has a smooth body covered with spongiose material only in the apical part. A similar "irregularly lobed substance" in the apical part is mentioned by Dijkstra (1959) in $R$. pileata (Dijkstra) Singh, 1983, from the Maastrichtian of Limburg. The studied material is covered by this substance over nearly whole body, except for the distal apex. However, Lupia (2015) found out that megaspores can lose substantial portions of this spongiose structure. A similar structure has been described in spores of Recent Selaginella by Korall and Taylor (2006), particularly in species $S$. pygmaea and S. gracillima. Unlike these species, two of our fossil specimens have this mass more extended (Figure 2A, C).

Range. Late Coniacian or early Santonian age.

Occurrence. Rakowice Małe locality.

Material studied. K 3014-3019; the material is housed in the National Museum Prague.

Division GYMNOSPERMAE (Lindley, 1830) Prantl,
1874
Class CONIFERAE (de Jussieu, 1789) Engler,
1892
Order PINALES Gorozhankin, 1904
Family CUPRESSACEAE Gray, 1821
Genus CUNNINGHAMITES Presl in Sternberg,
1838

Type species. Cunninghamites oxycedrus Presl in Sternberg, 1838 , p. 203, pl. 48, figs. 3a-c, pl. 49, figs. 1a, b from Late Cretaceous, Cenomanian; Niederschöna, Saxony, Germany.

Remarks. The leaves are dorsiventrally flattened with expanded leaf cushions, and adaxially showing two distinct bands of stomata, characters that indicate the genus Cunninghamites Presl in Sternberg. 

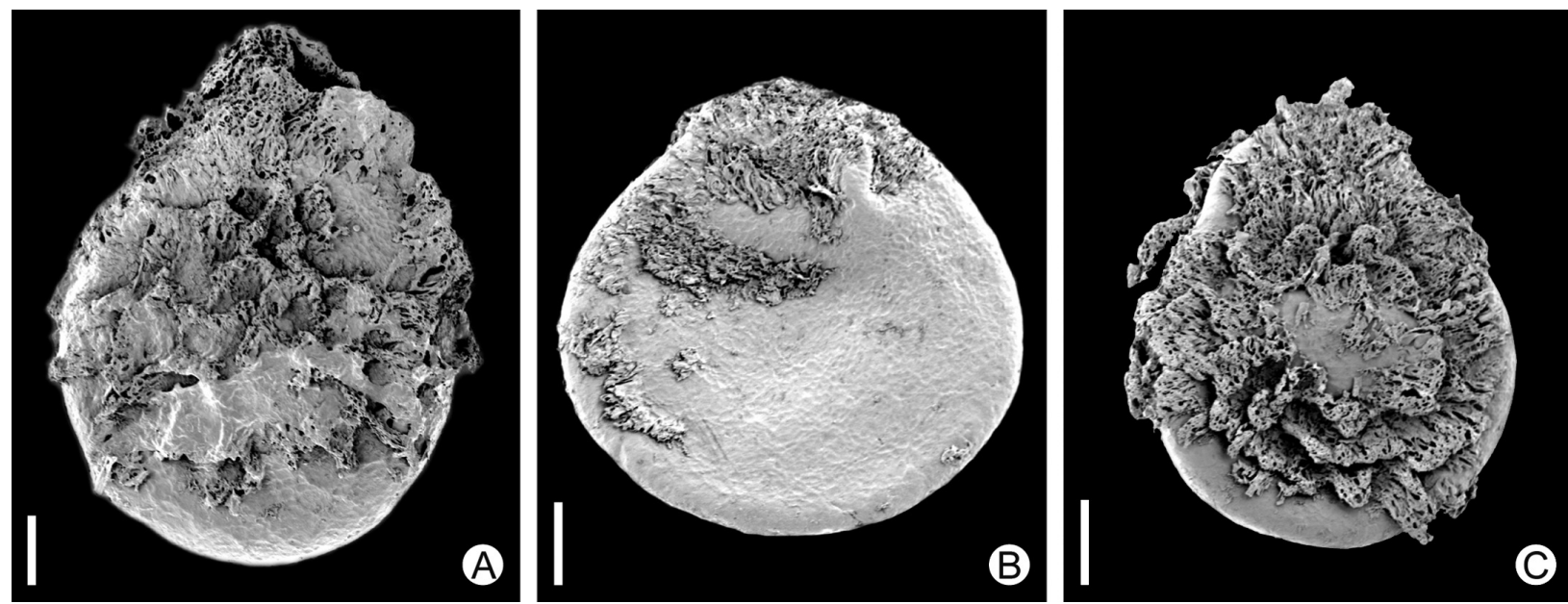

FIGURE 2. Ricinospora sp. (A) and (C) showing that nearly the whole megaspore is covered with spongiose material, (B) spongiose exinal strengthenings is mainly in the proximal part of spore, a fragment of the trilete laesure is visible. Scale bar for all images $0.1 \mathrm{~mm}$. All specimens from Rakowice Małe locality.

Cunninghamites cf. squamosus Heer, 1871 Figure 3A-C

1871 cf. Cunninghamites squamosus Heer, p. 9, pl. 1, figs. 5-7.

1880 cf. Cunninghamites recurvatus Hosius et von der Marck, p. 178, pl. 37, figs. 143, 144.

1905 cf. Cunninghamites pulchelles Knowlton, $p$. 136, pl. 16, fig. 1.

1910 cf. Cunninghamites elegans (Corda) Endlicher; Berry, p. 186, pl. 20, figs. 1-4

1919 cf. Elatocladus elegans (Corda) Seward, p. 433, figs. 804, 805.

1922 cf. Elatocladus elegans (Corda) Seward; Kräusel, p. 10, pl. 1, figs. 4-10; pl. 2, figs. 1-5; pl. 3, figs. 1,2; Text figs. 4,5 .

1925 cf. Cunninghamites elegans (Corda) Endlicher; Berry, p. 33.

2000 cf. Elatocladus elegans (Corda) Seward; Rüffle and Trostheide, p. 434, pl. 1, fig. 6; pl. 2, fig. 2; pl. 3, fig. 1.

2009 cf. Cunninghamites squamosus Heer; Bosma et al., p. 486, fig. 4c-f; fig. 5.

2012 cf. Cunninghamites squamosus Heer; Bosma et al., p. 24, pl. 1, figs. 5-6, pl. 2, figs. 4, 7.

Lectotype. Designated by Bosma et al. (2012), No. 6166 (ex coll. Schenk in the Würzburg University), Late Cretaceous, late Santonian, "Altenburg" near Quedlinburg, Germany.

Description. The material consists of fragments of branches. The terminal part of the sterile twig 8 $\mathrm{mm}$ long and $4.0 \mathrm{~mm}$ broad shows needles packed in a pointed bud (Figure $3 \mathrm{~A}$ ). A fragment of an axis (4.0 mm long) shows helically arranged basal parts of needle-like leaves. A nearly complete isolated leaf $5.0 \mathrm{~mm}$ long, shows basally broadened leaf cushion (Figure 3B). Its cuticle shows adaxially two clearly distinct stomatal bands (Figure 3C). Stomata tend to be orientated perpendicularly to the leaf margin.

Remarks. The material resembles the type material designated by Bosma et al. (2009). However, it is too fragmentary to allow precise comparison. We found minor differences in the studied material from the type, so open nomenclature is used. Particularly the leaves of the studied material show only one rib/keel and contained probably only one vein. Its stomata are orientated perpendicularly to the leaf margin, while the type material shows a random orientation (Bosma et al., 2012, 2009).

Range. Late Coniacian or early Santonian age.

Occurrence. Żeliszów locality.

Material studied. K 2940, K 2948, K 2953, K 2956; the material is housed in the National Museum Prague.

\section{Genus ALAPAJA Dorofeev, 1979}

Type species. Alapaja uralensis (Dorofeev, 1979), p. 314, figs 1, 5-10, fig. 7, 1-10

Remarks. Based on the presence of a structure very probably representing a curved embryo, asymmetric wings, pronounced funiculus and due to the overall shape of the seed, we assign the seed to the genus Alapaja. Alapaja differs from Seletya Dorofeev and Kozykorpeshia Dorofeev in having a marginal crest, being less curved, and lacking a basiventral micropyle (Dorofeev, 1979; Kunzmann and Friis, 1999).

\section{Alapaja sp.}

Figure 3G 

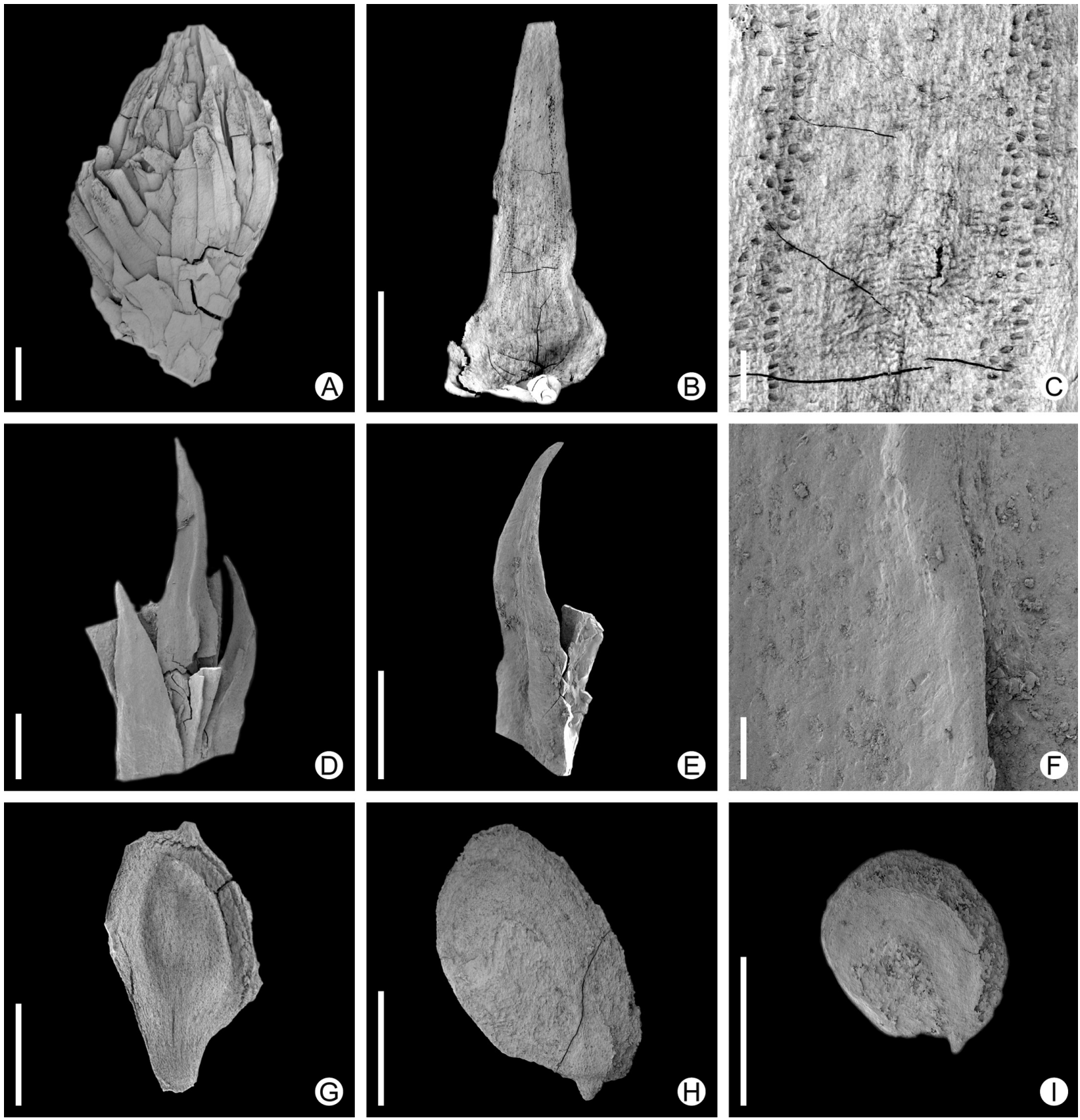

FIGURE 3. Conifers (A) Cunninghamites cf. squamosus terminal fragment of twig, no. K2948, scale bar $1 \mathrm{~mm}$ (B) Cunninghamites cf. squamosus isolated leaf with leaf cushion, no. K2956, scale bar $1 \mathrm{~mm}$ (C) Cunninghamites cf. squamosus adaxial cuticle showing two bands of stomata, no. K2956, scale bar $100 \mu \mathrm{m}$ (D) Geinitzia formosa, fragment of twig, no. K2958a scale bar $1 \mathrm{~mm}$ (E) Geinitzia formosa, isolated leaf with keel, no. K2958b scale bar $1 \mathrm{~mm}$ (F) Geinitzia formosa, detail of abaxial cuticle showing two irregular stomatal bands, no. K2958b scale bar $100 \mu \mathrm{m}$ (G) Alapaja sp. seed, no. K2962 scale bar $1 \mathrm{~mm}(\mathrm{H})$ Seletya sp. seed no. K 3012 scale bar $1 \mathrm{~mm}$ (I) Seletya sp. seed no. K 3013, scale bar $1 \mathrm{~mm}$. All specimens from Żeliszów locality.

Description. Seed is $2.7 \mathrm{~mm}$ long, $1.4 \mathrm{~mm}$ broad, flattened, ovate, asymmetric, showing fragments of one narrow, inconspicuous wing and one wider wing (Figure 3G). Margin shows both large and smaller projections, forming a crest. Larger projections frequently broken off. Micropyle pointed and partly broken in terminal part. Basal part formed by distinctive funicle. Central part of the seed relatively smooth, showing a central depression and a curved structure representing an embryo.

Remarks. Although the seed is not well preserved, we decided to publish it here as unequivocally doc- 
umenting the presence of the genus at Rakowice Małe. Our seed is more similar to the type material of (Dorofeev, 1979) from the Cenomanian-Turonian of Alapayevsk (Yekaterinburg, east Ural). Our seed is smaller than Alapaja uralensis from the Turonian of Kazakhstan (Frumina et al., 1995)

Range. Late Coniacian to early Santonian age. Occurrence. Żeliszów locality.

Material studied. K 2962; the material is housed in the National Museum Prague.

\section{Genus SELETYA Dorofeev, 1979}

Type species. Seletya kryshtofovichii Dorofeev, 1979, p. 315, pl. 2, figs. 1-6, pl. 3, fig. 1, 2, pl. 8, figs. 1-6.

Remarks. Seeds of Seletya differ from Alapaja in having a smooth margin and a clearly projecting hilum. The type S. kryshtofovichii was transferred to Geinitzia by Knobloch and Mai (1986), but Geinitzia is based on sterile foliage, so from a nomenclatorial point of view this need not be accepted. We therefore applied a more conservative approach, and separated the seeds (and ovuliferous cones) from the sterile twigs Geinitzia formosa.

\section{Seletya sp.}

Figure $3 \mathrm{H}$, I

Description. Seeds small, 2.0-2.6 mm long, 1.6$1.4 \mathrm{~mm}$ broad, flattened, ovate to sub-circular showing a very narrow inconspicuous wing (Figure $3 \mathrm{H}, \mathrm{I})$. Locule curved campylotropous, hilum and micropyle basiventral, hilum circular, broad, micropyle pointed and conspicuous. Seed coat rugulose, pits quadrangular or polygonal, rarely oblong, arranged in regular parallel grooves following curvature of seeds.

Remarks. The described seeds are reminiscent of Seletya krishtofovichii from the Cenomanian of Kazakahstan (Dorofeev, 1979) and Santonian of Quedlinburg (Knobloch and Mai, 1986) in number of characters e.g. in having a very narrow wing and a conspicuous micropyle. An ovuliferous cone comparable to that described by Kunzmann (1999) attached to twigs of Geinitzia formosa was described from the studied area and stratigraphic horizon (Rakowice Małe) by Halamski et al. (2020). The seeds of similar shape are found in ovuliferous cones Fricia nobilis Velenovský, described from the Turonian of the Bohemian Cretaceous Basin (Kvaček, 2013).

Range. Late Coniacian or early Santonian age.

Occurrence. Żeliszów locality.

Material studied. $\mathrm{K} 3012, \mathrm{~K} 3013$; the material is housed in the National Museum Prague.

\section{Family GEINITZIACEAE Kunzmann, 1999} Genus GEINITZIA Endlicher, 1847

Type species. Araucarites reichenbachii Geinitz, 1842 , p. 98, pl. 24, 4 = Geinitzia reichenbachii (Geinitz) Hollick and Jeffrey, 1909, p. 38, pl. 5, figs. $7-10$, pl. 8 , figs. 3,4 , pl. 16 figs. $2-4$, pl. 17 figs. $1-4$, pl. 18, figs. $1-4$

Remarks. The material of sterile shoots is assigned to this genus, as suggested by Harris (1969) and Harris et al. (1979). It is characterised by helically arranged needles that are triangular in cross-section, and having a conspicuous keel. Our material shows all those characters very clearly.

Geinitzia formosa Heer, 1871

Figure 3D-F

v 1871 Geinitzia formosa Heer, p. 6, pl. 1, fig. 9, pl. 2, figs. 1-6

v.1999 Geinitzia formosa Heer, Kunzmann, p. 114, pl. 26 , figs. $1-8$, pl. 27 , figs. $1,5-10$, pl. 28 , figs. 1-6

2003 Geinitzia formosa Heer, Kunzmann, p. 13, fig. 4A-D, pl. 4, figs. 1-9

Lectotype. No. UW 3936, designated by Zijlstra et al. (2010), based on Kunzmann (1999), pl. 27, fig. 1, coll. University of Würzburg, Germany, Late Cretaceous, Santonian, Quedlinburg.

Description. Fragments of sterile twigs 1.0-2.0 $\mathrm{mm}$ broad, 4.0-13.0 $\mathrm{mm}$ long, with helically arranged needle-like leaves (Figure 3D), 1.5-4.5 $\mathrm{mm}$ long and $0.6-0.8 \mathrm{~mm}$ broad. Leaves triangular in cross section, showing a conspicuous keel (Figure 3E). Sometimes amber droplets preserved adhering to twigs. Abaxial cuticle shows two bands of stomata 200-500 $\mu \mathrm{m}$ broad (Figure 3F), the same arrangement is on abaxial cuticle. Stomata surrounded by 5-6 subsidiary cells. Stomatal axes irregularly orientated. Ledges of guard cells sunken in shallow stomatal chambers, sometimes surrounded by a slightly raised stomatal rim.

Remarks. We assign the studied material to Geinitzia formosa, as described from the type locality at Quedlinburg by Kunzmann (1999), particularly on account of leaves that are amphistomatic and triangular in cross section in terminal parts. G. formosa differs from $G$. reichenbachii in having shorter needles, which are frequently s-shaped. The needles of $G$. formosa are rhomboidal only in their basal parts, they are triangular terminally. G. formosa differs from Cunninghamites cf. squamosus, in having more three dimensional leaves. Leaves of Cunninghamites cf. squamosus are flattened in cross section, and their cuticle shows irregularly orientated stomata forming two bands. We also collected Seletya seeds in 
association, similarly to the situation described by Kunzmann (1999). However, Kunzmann did not make the nomenclatorial distinction between seeds and twigs, assigning seeds described herein under Seletya directly to Geinitzia (Kunzmann, 1999) along with sterile shoots.

Range. Late Coniacian or early Santonian age. Occurrence. Żeliszów locality.

Material studied. NMP K 2933-5, 2942-6, 2947, 2955, 2958, 3009; the material is housed in the National Museum Prague.

\section{Division ANGIOSPERMAE Brown and Doell ex Doell, 1857 \\ Class Dicotyledoneae de Candolle, 1824 \\ Order FAGALES Engler, $1892 \mathrm{s.l}$. Genus CARYANTHUS Friis, 1983}

Type species. Caryanthus knoblochii Friis, 1983, p. 172 , pl. 5 , 6 , 7, figs. $1-4$

Remarks. Fruits of the genus Caryanthus are small, ribbed, bisymmetrical and epigynous, nuts supported by a bract showing single erect seed (Friis, 1983; Friis et al., 2011, 2006; Heřmanová et al., 2016). In some cases, remains of perianth are preserved. They show a perianth consisting of four tepals arranged in two decussate pairs. The androecium is built of six to eight stamens. The gynoecium is bicarpellate, with a unilocular ovary and two free styles. Pollen is triaperturate and triangular in equatorial outline. A distinct Y-shaped mark extends between the apertures over the pole.

\section{Caryanthus communis Friis, 1983}

\section{Figure 4A-C}

v1964 Microcarpolithes triasseris Knobloch, (Knobloch, 1964) p. 170, pro parte.

v1983 Caryanthus communis Knobloch and Mai, (Knobloch and Mai, 1983) p. 308, pl. 8, figs. 5, 8, 11-13.

v1986 Caryanthus communis Knobloch et Mai, (Knobloch and Mai, 1986), p. 75, pl. 5, figs. 18,19.

v2006 Caryanthus communis Knobloch et Mai; (Friis et al., 2006) p. 113.

v2016 Caryanthus communis Knobloch et Mai; (Heřmanová et al., 2016) p. 36, pl.1, figs. 1-9.

Holotype. No. NMP F 3577, published by Knobloch and Mai (1983); pl. 8, fig. 5, stored in the National Museum Prague, Late Cretaceous, Upper Turonian-Santonian, České Budějovice - Rožnov borehole GB-3190.0-3190.1 m, Czech Republic.

Description. Single specimen from Rakowice Małe locality, flat fruit of ovoid shape (Figure 4A). Length $1.3 \mathrm{~mm}$; breadth $0.8 \mathrm{~mm}$. Apical part of fruit concave (Figure 4B). Persistent perianth fused basally, forming hypanthium. Tepals attached on the top of hypanthium. Tepals not preserved; their insertion indicated by attachment scars, indicating four tepals in two decussate pairs. Lateral face of fruit shows a long concave tepal attachment scar, placed mid-way between the base and the apex. Medial scars small, close to the base. The lateral face of the fruit shows a diamond shaped area. Length of this area $0.9 \mathrm{~mm}$; breadth of fruit $0.7 \mathrm{~mm}$. Epidermis of the fruit composed of small irregular cells (Figure 4C).

Remarks. The specimen from the Rakowice Małe locality is slightly longer than other fruits of Caryanthus communis (Heřmanová et al., 2016). The species Caryanthus communis is described as having a concave base, but the specimen from Rakowice Małe has slightly pointed base. However, absence of this character may be due to poor preservation of the specimen.

Range. Late Coniacian or early Santonian age.

Occurrence. Rakowice Małe locality.

Material studied. K2899; the material is housed in the National Museum Prague.

Caryanthus trebecensis Knobloch and Mai, 1983 Figure 4D-F

v1983 Caryanthus trebecensis Knobloch et Mai; Knobloch and Mai, 1983, p. 309, pl. 8, figs.1-4, 10, 14.

v1986 Caryanthus trebecensis Knobloch et Mai; Knobloch and Mai, 1986, p. 76, pl. 5, fig. 4.

v2006 Caryanthus trebecensis Knobloch et Mai; Friis et al., 2006, p. 113.

v2012 Caryanthus sp.; Heřmanová and Kvaček, 2012, p. 49 , pl. 2, figs. A-G.

v2016 Caryanthus trebecensis Knobloch et Mai; Heřmanová et al., 2016, p. 42, pl. 6, figs 1-12.

Holotype. Published by Knobloch and Mai (1983), pl. 8, figs. 1-3, stored in the National Museum Prague NMP F3873, Late Cretaceous, Upper Turonian-Santonian, Branišov $\mathrm{Br} 21$ borehole, 23.0$23.5 \mathrm{~m}$, Czech Republic.

Description. The specimen from Rakowice Małe locality is a slightly deformed fruit of ellipsoid shape (Figure 4D). Length $1.4 \mathrm{~mm}$; breadth $1.0 \mathrm{~mm}$. Apical part of the fruit concave; persistent perianth fused basally forming hypanthium, which covers the entire fruit (Figure 4E). Lateral faces of the fruit show two deeply sunken ridges running from the base to the apex. Surface covered with irregularly shaped thick-walled cells. Periclinal wall of cells sometimes collapsed (Figure 4F).

Remarks. The specimen from the Rakowice Małe locality is slightly longer than other fruits of Caryanthus trebecensis (Heřmanová et al., 2016). The apical part of the specimen described here is 

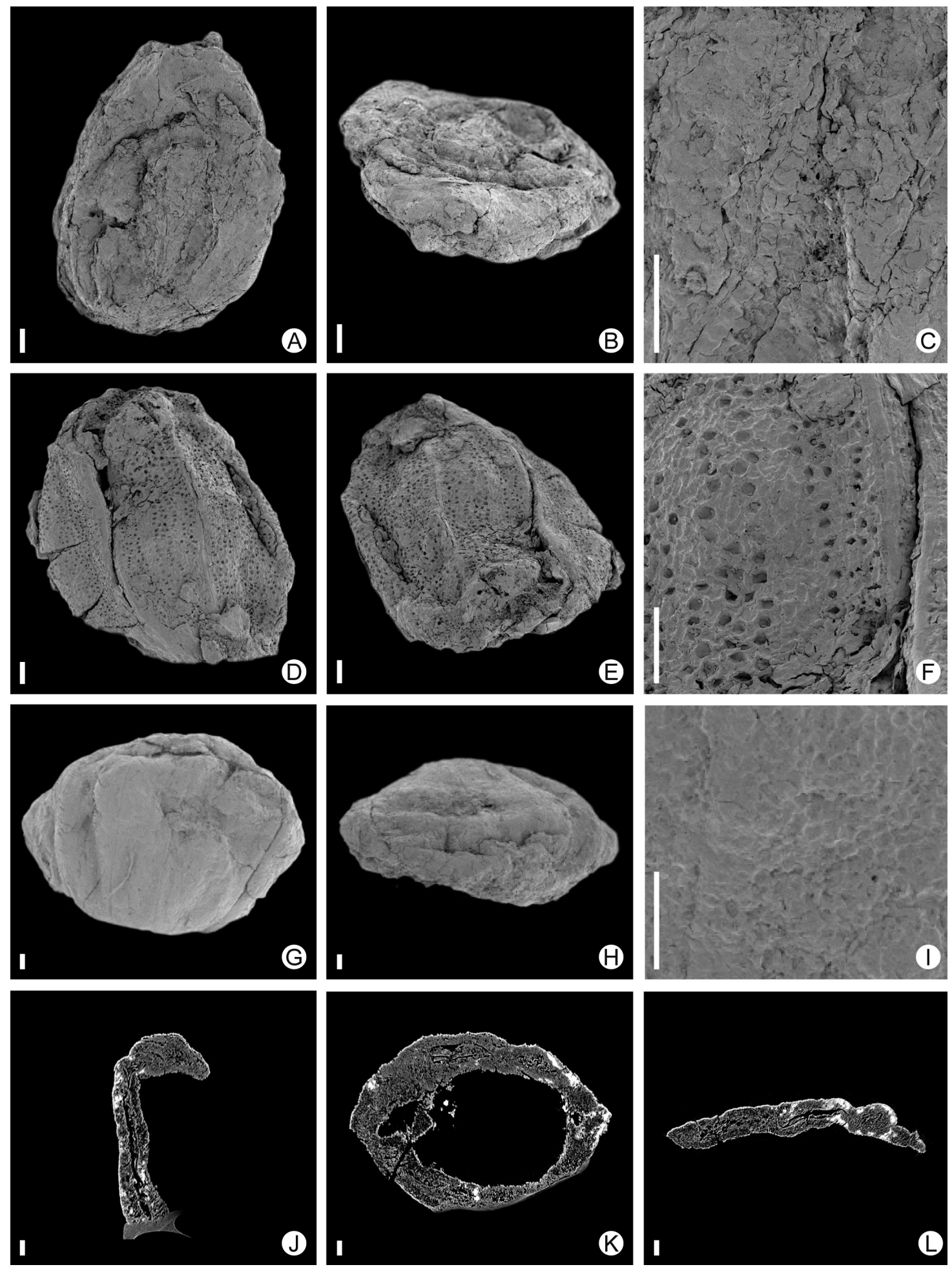

FIGURE 4. Caryanthus (A) Caryanthus communis broadly elliptical fruit, no. K2899; (B) Caryanthus communis apical part of fruit, no. K2899; (C) Caryanthus communis detail of epidermis, no. K2899 (D) Caryanthus trebecensis ribbed fruit, no. K2900; (E) Caryanthus trebecensis apical part of fruit, no. K2900; (F) Caryanthus trebecensis detail of epidermis, no. K2900; (G) Caryanthus sp. ribbed fruit, no. K2906; (H) Caryanthus sp. apical part of fruit, no. K2906; (I) Caryanthus sp. detail of epidermis, no. K2906; (J) Caryanthus sp. X-ray image, longitudinal/lateral section of fruit, no. K2906; (K) Caryanthus sp. X-ray image, transversal section of fruit, no. K2906; (L) Caryanthus sp. X-ray image longitudinal/adaxial-abaxial section of fruit, no. K2906. Scale bar for all images $0.1 \mathrm{~mm}$. All specimens from Rakowice Małe locality. 
deformed, thus shape and position of tepals, usually attached on top of the hypanthium, are unclear. Range. Late Coniacian or early Santonian age. Occurrence. Rakowice Małe locality. Material studied. K2900; the material is housed in the National Museum Prague.

Caryanthus triasseris Knobloch (Knobloch and Mai), 1983

Figure $5 \mathrm{~A}-\mathrm{F}$

v1964 Microcarpolithes triasseris Knobloch; (Knobloch, 1964) p. 170, pl. 5, fig. 6.

v1970 Microcarpolithes octocostatus Knobloch; (Knobloch, 1970), pl. 11, figs. 4, 16, 17.

v1971 Microcarpolithes octocostatus Knobloch; (Knobloch, 1971) p. 27, pl. 6, figs. 1-5, 9, 11.

v1971 Microcarpolithes triasseris Knobloch; (Knobloch, 1971) p. 21-5, pl. 3, figs. 1-8 (non figs.914), non pl. 6, figs. 12-13, pl. 10, fig. 5.

v1977 Microcarpolithes triasseris Knobloch; (Knobloch, 1977) p. 113-114, pl. 1, figs. 5, 9,11, 13, $16,18,19$, pl. 2 , figs. 8,10 , pl. 4 , figs. 25,26 , pl.5 figs. 13, 21-23 pl.11, 6-9.

v1983 Caryanthus triasseris (Knobloch) Knobloch et Mai; (Knobloch and Mai, 1983) p. 309, pl. 6, figs. 4,5 (non pl. 6 fig. 11), (non pl. 8 fig. 6), pl. 9, fig. 8 , pl. 10 fig. 9 .

v1986 Caryanthus triasseris (Knobloch) Knobloch et Mai; (Knobloch and Mai, 1986) p. 76, pl.5 figs.

1-3. non (figs. 7-10), (non pl. 6 fig. 18).

v2006 Caryanthus triasseris (Knobloch) Knobloch et Mai; (Friis et al., 2006) p. 113.

v2016 Caryanthus triasseris (Knobloch) Knobloch et Mai; (Heřmanová et al., 2016) p. 44 pl. 7 figs. 111.

Holotype. Published by Knobloch (1964); pl. 5, fig. 6 , stored in the National Museum Prague No. NMP F 3611, Late Cretaceous, Upper Turonian-Santonian, Včelná borehole GB2 119.5-119.8 m, Czech Republic.

Description. Four specimens from Rakowice Małe locality are fruits, round to elliptical in shape. Length 0.9-1.3 mm (arithmetic mean $1.0 \mathrm{~mm}$ ); breadth 0.7-1.1 (arithmetic mean 0.1). Three specimens round (Figure 5A), one elongated (Figure $5 \mathrm{D})$. Apical part of fruit pointed or slightly pointed (Figure 5B, E), as well as its base. Perianth persistent, fused basally, forming a hypanthium, which extends for almost the entire length of fruit. Lateral faces of fruit have three very indistinct ribs running from the base to the margin of hypanthium.

Discussion. Specimens of Caryanthus triasseris from the Rakowice Małe locality are above average in size of the fruits, compared to the type material (Knobloch and Mai, 1986). The ribs that are very characteristic for the species run from the base to the margin of the hypanthium. However, this character is very indistinct in material from Rakowice Małe.

Range. Late Coniacian or early Santonian age.

Occurrence. Rakowice Małe locality.

Material studied. NM K2898; K2901; K2902; K2907; the material is housed in the National Museum Prague.

\section{Caryanthus sp. \\ Figure 4G-L}

Description. The single specimen from the Rakowice Małe locality is a slightly deformed flattened fruit, ellipsoid in shape (Figure 4G). Length 1.4 $\mathrm{mm}$; breadth is $2.0 \mathrm{~mm}$. Apical part of the fruit concave and strongly deformed (Figure $4 \mathrm{H}$ ). Basal part convex. Persistent perianth fused basally, forming hypanthium, which covers the entire fruit. Lateral faces of fruit show five slightly sunken ridges running from base to apex, surface covered with irregular thick-walled cells (Figure 4I). Distinct compact outer and inner layers of the fruit wall consist of small cells. The middle layer has larger cells (Figure 4J-L).

Remarks. Lateral face of Caryanthus trebecensis shows two to four sunken ridges, lateral face of Caryanthus triasseris shows three parallel ribs and lateral face of this fruit shows five slightly sunken ridges so it is difficult to decide to which species this specimen belongs, either to $C$. trebecensis or C. triasseris.

Range. Late Coniacian or early Santonian age.

Occurrence. Rakowice Małe locality.

Material studied. K2906; the material is housed in the National Museum Prague.

Genus ZLIVIFRUCTUS Heřmanová, Dašková et J. Kvaček, 2017

Type species. Zlivifructus vachae Heřmanová, Dašková et J. Kvaček (Heřmanová et al., 2017)

Remarks. The genus represents small flowers and fruits. The flowers are bisexual, bisymmetrical and have an inferior ovary with a hypanthium. The tepals are attached on top of the hypanthium. The genus has four tepals, in two decussate pairs. The androecium consists of four stamens. The gynoecium is bicarpellate, with a unilocular ovary and two styles. Fruits are nuts with a single erect seed. Normapolles pollen grains of Plicapollis-type were found on the surface of the fruit (Heřmanová et al., 2017).

\section{Zlivifructus vachae Heřmanová, Dašková et J. Kvaček, 2017 Figure 6A-I}



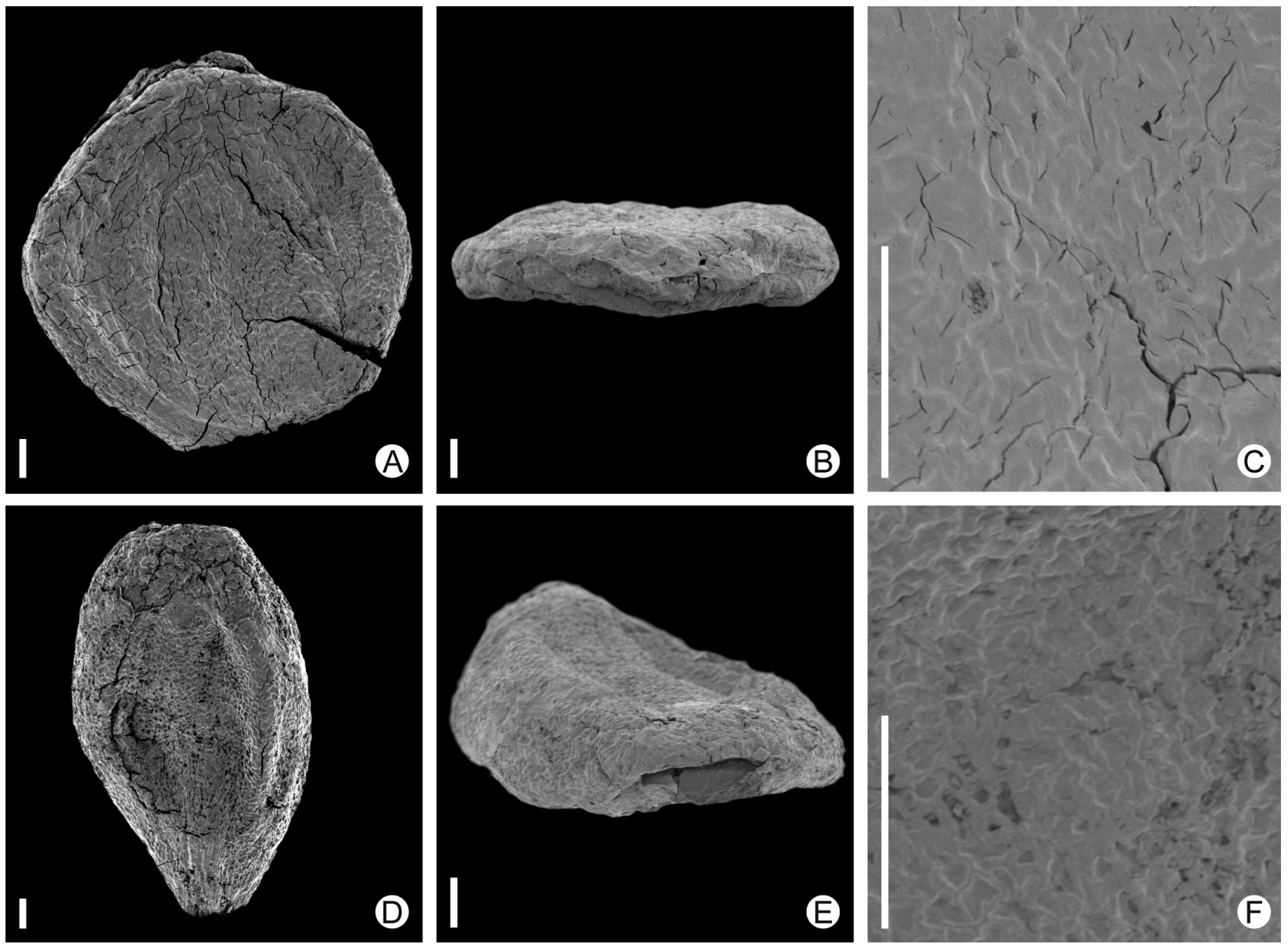

FIGURE 5. Caryanthus triasseris (A) ribbed fruit round in outline, no. K2901 (B) apical part of fruit, no. K2901 (C) detail of epidermis, no. K2901 (D) ribbed fruit elliptical in outline, no. K2907 (E) apical part of fruit, no. K2907 (F) detail of epidermis, no. K2907. Scale bar for all images $0.1 \mathrm{~mm}$. All specimens from Rakowice Małe locality.

v2017 Zlivifructus vachae Heřmanová, Dašková et J. Kvaček; (Z. Heřmanová et al., 2017) p. 181, pl. 1, figs. 1-9, pl. 2, figs. 1-7, pl. 3, figs. 1-2.

Holotype. Selected and illustrated by Heřmanová et al. (2017), pl. 1, fig. 1, stored in the National Museum Prague No. NMP F4557, Late Cretaceous, Upper Turonian-Santonian, Třebeč TSv-5 borehole 106.5-107 m, Czech Republic.

Description. Two specimens from Rakowice Małe locality are round fruits, flattened to some degree. One almost completely flat (Figure 6A); the other more ovoid (Figure 6D). Lengths 1 and $0.9 \mathrm{~mm}$; breadths 1.1 and $0.7 \mathrm{~mm}$. Apical part of fruits convex, basal parts show scar where fruits were attached to infructescence (Figure 6B, E). Persistent perianth fused basally, forming hypanthium, which covers two-thirds of fruit. Lateral faces of the fruit show three indistinct ribs extending from base of fruit to margin of hypanthium. Androecium consists of four stamens (Figure 6D), but only basal parts of stamens are preserved. Distinct compact outer layers of the fruit wall consist of small cells. The middle layer has larger cells (Figure 6G-I).Surface covered with irregular thick-walled cells (Figure 6F).

Remarks. The present material seems to match the main diagnostic characters of the type, but it is poorly preserved. Tepals are absent in both specimens, but we interpret the preserved scars as resulting from detachment of tepals. We assume tepals attached on top of the hypanthium. Scars are immediately adjacent to each other, with indistinct boundaries and the scars form a roughly regular ring.

Range. Late Coniacian or early Santonian age.

Occurrence. Rakowice Małe locality.

Material studied. K2905, K2903; the material is housed in the National Museum Prague.

Zlivifructus microtriasseris (Knobloch et Mai) Heřmanová, J.Kvaček et Halamski 2019

Figure 7A-C 

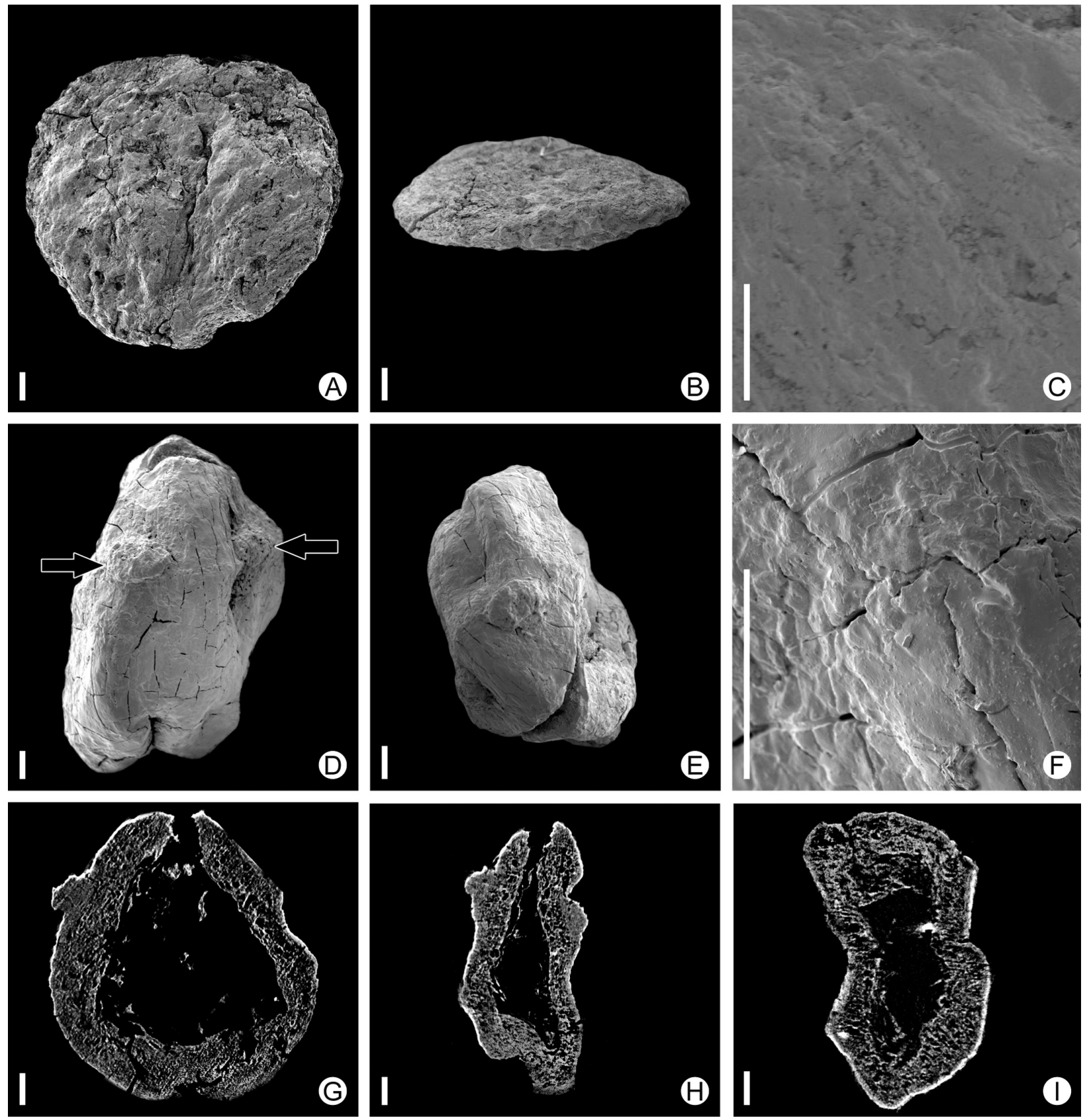

FIGURE 6. Zlivifructus vachae (A) fruit, round in outline, no. K2903 (B) apical part of fruit, no. K2903 (C) detail of epidermis, no. K2903 (D) fruit, basal pats of stamens arrowed, no. K2905 (E) apical part of fruit, no. K2905 (F) detail of epidermis, no. K2905 (G) X-ray image, longitudinal/adaxial-abaxial section of fruit, no. K2905 (H) X-ray image, longitudinal/lateral section of fruit, no. K2905 (I) X-ray image, transversal section of fruit, no. K2905. Scale bar for all images $0.1 \mathrm{~mm}$. All specimens from Rakowice Małe locality.

v1983 Caryanthus microtriasseris Knobloch et Mai; (Knobloch and Mai, 1983) p. 308-309, pl.8, fig. 9.

v1986 Caryanthus microtriasseris Knobloch et Mai; (Knobloch and Mai, 1986) p. 76, pl. 5, figs. 5-6, pl. 55, fig. 3.

v2006 Caryanthus microtriasseris Knobloch et Mai; (Friis et al., 2006) p. 113. v2016 Caryanthus microtriasseris Knobloch et Mai; (Heřmanová et al., 2016) p. 40, pl. 5, figs. 1-3.

v2019 Zlivifructus microtriasseris (Knobloch et Mai) Heřmanová, J. Kvaček, Halamski in (Heřmanová et al., 2019), p. 90, p. 11, figs. 1-9. Holotype. No. NMP F3872, selected and illustrated by Knobloch and Mai (1983); pl. 8 fig. 9, stored in the National Museum Prague, Late Creta- 

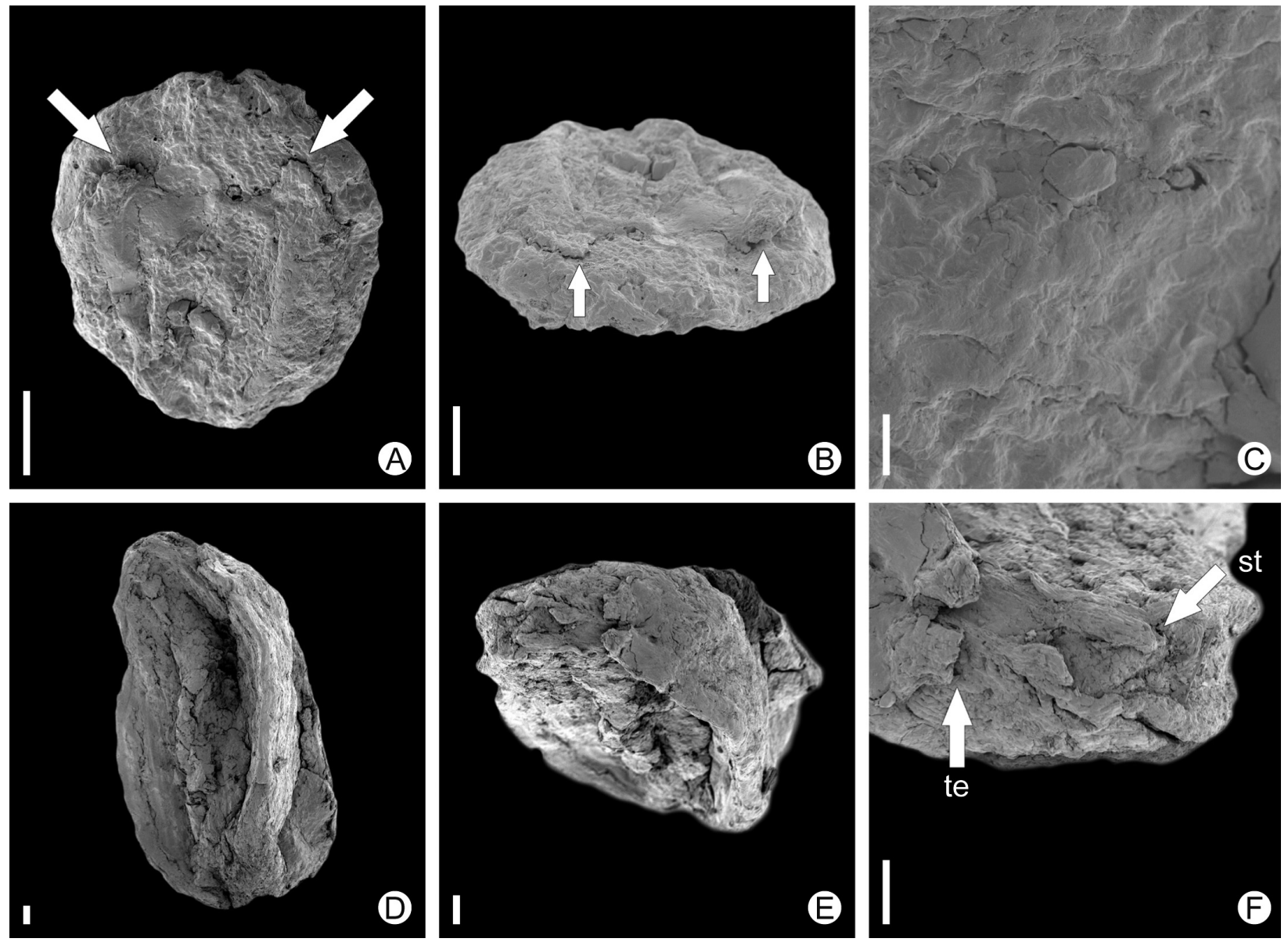

FIGURE 7. Fruits of Normapolles (A) Zlivifructus microtriasseris small fruit, basal parts of stamens arrowed, no. K 1290 (B) Zlivifructus microtriasseris apical part of fruit, basal parts of stamens arrowed, no. K 1290 (C) Zlivifructus microtriasseris detail of epidermis, no. K 1290 (D) Normapolles aff., deformed fruit, no. K2904 (E) Normapolles aff., apical part of the fruit, no. K2904 (F) Normapolles aff., apical part of the fruit, basal pats of stamens arrowed (st), basal parts of two very narrow tepals arrowed (te), no. K2904. Scale bar for all images $0.1 \mathrm{~mm}$. All specimens from Rakowice Małe locality.

ceous, Upper Turonian-Santonian, Záblatí borehole 65/21, 34.0-35.0, Czech Republic.

Description. The single specimen from Rakowice Małe locality is a small, flat fruit, round in outline (Figure 7A). Length $0.4 \mathrm{~mm}$; breadth $0.4 \mathrm{~mm}$. Apical part of the fruit concave (Figure 7B), basal part convex. Persistent perianth fused basally, forming hypanthium, which extends more than two thirds of the fruit. Tepals not preserved; but scars indicating their insertion present. Lateral attachment scars of tepals and medial attachment scars immediately adjacent to each other, with indistinct boundaries forming a ring. Androecium consists of four stamens (Figure 7B), but only basal parts of stamens are preserved. Lateral faces of the fruit show two parallel ribs running from base of fruit to margin of hypanthium.
Remarks. This specimen was revised in Heřmanová et al. (2019). Fowers and fruits of Zlivifructus microtriasseris, originally described as Caryanthus microtriasseris from the North Sudetic Basin and South Bohemian Basins (late Turonian Santonian) were reinterpreted. Zlivifructus microtriasseris differs from species assigned to genus Caryanthus Friis (1983) in the presence of four stamen scars, and in having two lateral ribs in the face of the fruit (Heřmanová et al., 2019).

Range. Late Coniacian or early Santonian age.

Occurrence. Rakowice Małe locality.

Material studied. K 1290; the material is housed in the National Museum Prague.

Family unknown

Fruit of Normapolles affinity

Figure 7D-F 
Description. One specimen from Rakowice Małe locality is a slightly deformed fruit, elliptic in outline (Figure 7D). Length $2.1 \mathrm{~mm}$; breadth $1.0 \mathrm{~mm}$. Apical part of fruit slightly pointed. Perianth persistent, fused basally, forming hypanthium, which extends for almost entire length of fruit. Tepals attached on top of hypanthium. Basal parts of two, very narrow tepals are preserved (Figure 7F). Lateral faces of fruit strongly deformed, epidermis largely destroyed.

Remarks. The number of stamens is not clear, so it is difficult to decide to which genus the specimen belongs, but probably to Caryanthus or Calatiocarpus.

Range. Late Coniacian or early Santonian age. Occurrence. Rakowice Małe locality.

Material studied. K2904; the material is housed in the National Museum Prague.

Pistillate flower of Normapolles affinity Figures 8A, 9A-C

Description. Specimen No. K2951 from Żeliszów shows a unit of flowers on a common short twig (Figures 8A, 9A), subtended by a common bract. The unit consists of three epigynous flowers, each subtended by a bract (Figure 9B). Length of flowers - 1.7-2.0 mm; breadth 0.9-1.2 mm. Each flower is extremely flattened consisting of five tepals (Figure $9 \mathrm{C}$ ) that are fused basally; their free parts are triangular, $0.4 \times 0.5 \mathrm{~mm}$ in size. The gynoecium is very flattened and of unknown structure (Figure 9A, C).

Remarks. The studied fragment of an inflorescence and its general construction argues for its systematic affinity to plants of the Normapolles Complex. However, more and better preserved material is necessary for closer comparison with other genera of the Complex.

Range. Late Coniacian or early Santonian age. Occurrence. Żeliszów locality.

Material studied. K2951; The material is housed in the National Museum Prague.

Staminate flower of Normapolles affinity Figure 8B-F

Description. The homogenous material consisting of three studied specimens from Żeliszów shows compound units, very probably fragments of larger inflorescences. The best preserved unit (Figure $8 \mathrm{~B}$ ) consists of three flowers, subtended by a massive bract. Length of each flower is $2.1-2.4 \mathrm{~mm}$ (Figure 8D). Each of the three flowers subtended by a small bract each consists of five oblanceolate $(0.5-0.7 \mathrm{~mm} \times 2.1-2.4 \mathrm{~mm})$ that are fused in their very basal parts (Figure $8 D, E$ ). The androecium of the flowers consists of several, probably five stamens. The stamens are preserved as basal parts of filaments. Each filament is covered by dense indumentum consisting of long unicellular trichomes. Trichomes occur also on external surfaces of tepals (Figure 8F), but in lower density. A loose fragment of an anther adhering to an inner part of one tepal in one flower (Figure 8B) shows pollen of Oculipollis type (Figure 8C).

Remarks. Absence of the gynoecium in the studied flowers suggests their possible dioecious character. Free oblanceolate tepals fused only in basal parts and flowers arranged in compound inflorescences recall in some way the genus Endressianthus Friis et al., described from the CampanianMaastrichtian of Portugal (Friis et al., 2003). However, the studied material differs from Endressianthus in having longer tepals and bearing a different pollen type found in situ.

Range. Late Coniacian or early Santonian age.

Occurrence. Żeliszów locality.

Material studied. K 2949, K2950, K 2952, K 2961; the material is housed in the National Museum Prague.

Kingdom OPISTHOKONTA Cavalier-Smith, 1987

Subkingdom ANIMALIA Linné, 1758

Phylum ARTHROPODA von Siebold, 1848

Class INSECTA Linné, 1758

Insect coprolite

Figure 10A-C

Description and remarks. The single specimen from Rakowice Małe is of ellipsoid shape (Figure $10 \mathrm{~A}$ ) and hexagonal in transverse section (Figure $10 \mathrm{~B}$ ). Length $0.7 \mathrm{~mm}$; breadth $0.4 \mathrm{~mm}$. Surface of the fossil is smooth. No inner structures documented from this fossil (Figure 10C). Fossil faecal pellets, also called coprolites, are associated with many Cretaceous mesofloras (Colin et al., 2011; Knobloch, 1971, 1977; Vangerow, 1954). Affinity of fossil insect coprolites traditionally assigned to Microcarpolithes hexagonalis Vangerow to recent Kalotermes (Isoptera) has been suggested by Colin et al. (2011).

Range. Late Coniacian or early Santonian age.

Occurrence. Rakowice Małe locality.

Material studied. K2768; the material is housed in the National Museum Prague.

\section{Kingdom, Phylum/Division, Class INCERTAE SEDIS \\ Genus COSTATHECA Hall, 1967}

Type species. Chrysotheca diskoensis Miner, 1935 , p. 590 , pl. 18 , figs. $1-10=$ Costatheca diskoensis (Miner) Hall, 1967, p. 1298, figs. 1-3. 

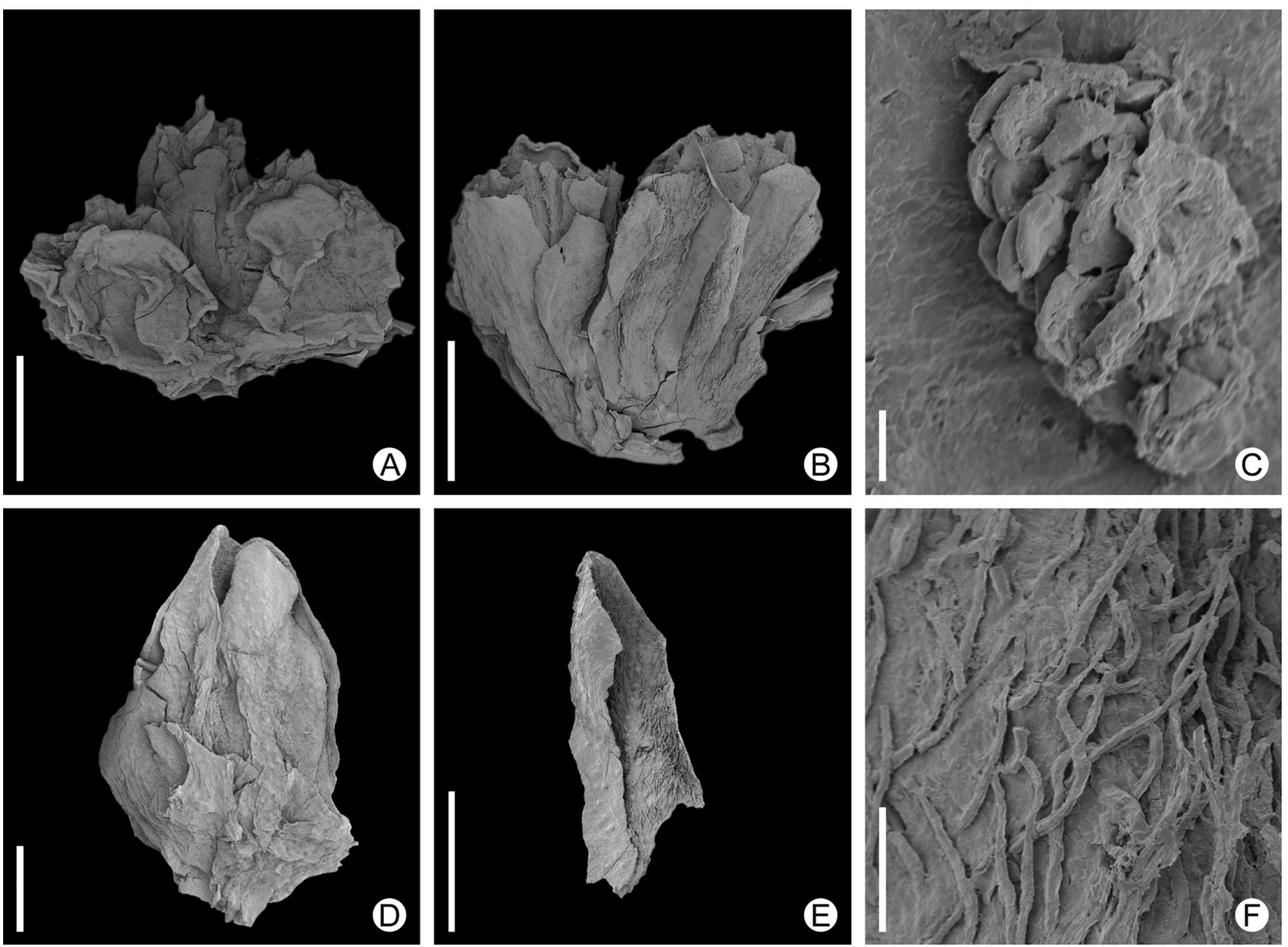

FIGURE 8. Inflorescence of Normapolles Complex (A) inflorescence formed by three pistillate flowers, no. K2951, scale bar $1 \mathrm{~mm}$ (B) inflorescence formed by three staminate flowers, no. K2950, scale bar $1 \mathrm{~mm}$ (C) detail showing pollen, no. K2950, scale bar $100 \mu \mathrm{m}$; (D) isolated staminate flower showing basal parts of five tepals (terminal part of one tepal removed), no. K2961, scale bar $0.5 \mathrm{~mm}$ (E) removed tepal from the specimen figured on image 8D, no. K2961 scale bar $0.5 \mathrm{~mm}$ (F) detail of indumentum from the specimen figured on image 8D, no. K2961 scale bar 50 $\mu \mathrm{m}$. All specimens from Żeliszów locality.

Remarks. The studied material shows typical parallel ribs and transversely orientated wrinkles characters typical for the genus Costatheca (Batten and Zavattieri, 1996, 1995; Knobloch, 1981).

Costatheca striata (Dijkstra 1949) Hall, 1967 Figure 10D, E

1949 Chrysotheca striata Dijkstra, p. 26, pl. 2, fig. 7.

1967 Costatheca striata (Dijkstra) Hall, p. 1298

1983 Costatheca striata (Dijkstra) Hall, Binda and Nambudiri, p. 2721, figs. 10, 12 (emended diagnosis).

For a more extensive synonymy see (Batten and Zavattieri, 1996, 1995).

Lectotype. Sample/slide 738-9. Maurits State Mine selected by Batten (1988, pl. 19, fig. 30).

Description. Elongate bodies, $2.2-2.5 \mathrm{~mm}$ long and $0.6-0.8 \mathrm{~mm}$ broad (Figure 10D, E); ends slightly S-shape curved. A more complete speci- men shows a scar (Figure 10E) that may represent the structure termed "operculum" by Batten and Zavattieri (1995). About ten ribs running parallel to the longitudinal axis, and less pronounced perpendicular structures resembling striation caused by thickly cutinised cells.

Remarks. According to Knobloch (1981), C. diskoensis shows a large variability in terms of size, shape and number of ribs. This opinion was questioned by Batten (1988), who studied the type material from Greenland, and who distinguished the specimens grouped by Knobloch into a separate species of Costatheca. Following Batten (1988), we assigned the studied material to C. striata (Dijkstra) Hall from the Santonian of Limburg (Dijkstra, 1949). C. striata was described from the Santonian of Limburg. This species differs from most species of Costatheca in having perpendicular striations. C. lata (Vangerov) Hall from the San- 

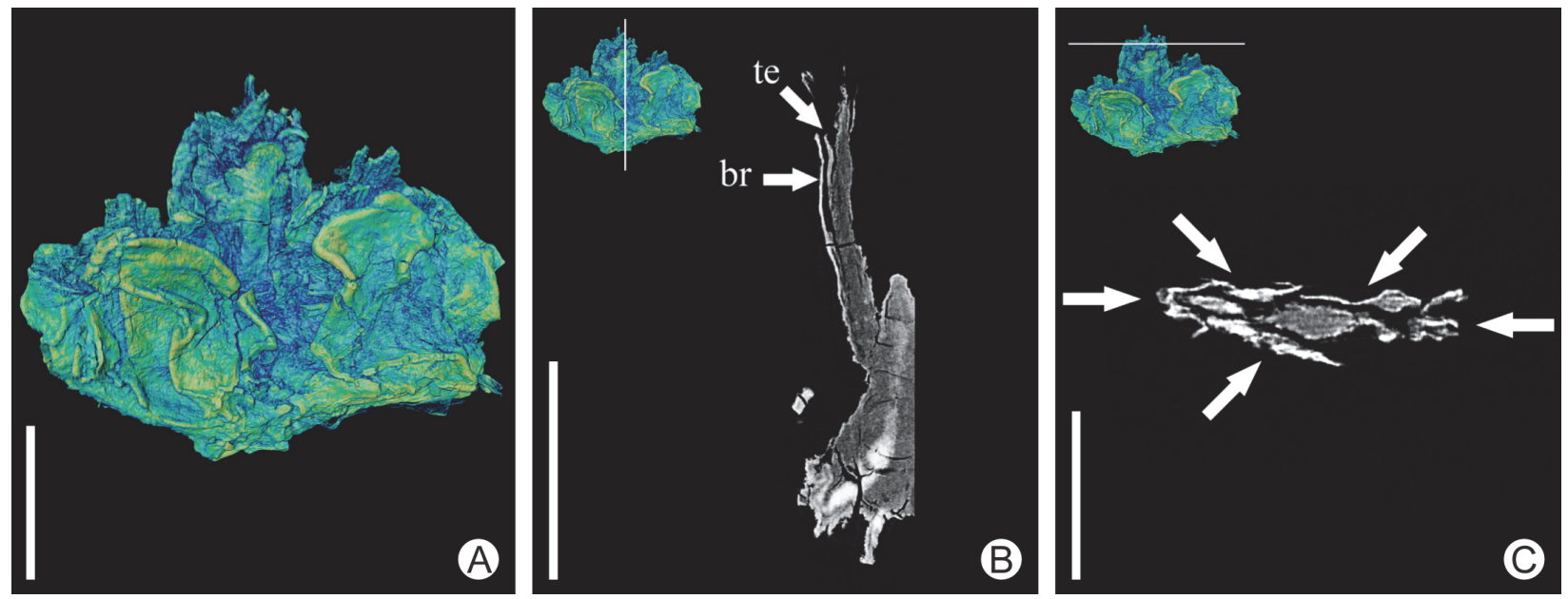

FIGURE 9. Flower of Normapolles affinity; X-ray pictures; specimen no. K2951. (A) inflorescence of three flowers; scale bar $1 \mathrm{~mm}$. (B) Cross section through one flower, showing bract (br) and tepal (te) and documenting the epigynous nature of the flower; scale bar $1 \mathrm{~mm}$. (C) Perianth of each flower consisting of five tepals (arrowed); scale bar 1 mm. Locality Żeliszów.

tonian of Aachen (Vangerow, 1954) differs from C. striata in having relatively low length/width ratio (Kovach and Dilcher, 1988). It is not clear what Costatheca represents. It could be an insect egg as suggested by Tiffney (1983) and Batten and Zavattieri (1995), whereas Binda and Nambudiri (1983) assumed that Costatheca could be related to the seeds of angiosperms of the Butomaceae family.

Range. Late Coniacian or early Santonian age.

Occurrence. Żeliszów locality.

Material studied. K 3010 , K 3011; the material is housed in the National Museum Prague.

\section{DISCUSSION}

Generally, Late Cretaceous mesofossil floras from central Europe are dominated by fruits of the Normapolles complex (Table 1). However, both localities studied herein show relatively low diversity of reproductive structures compared with other European Late Cretaceous assemblages (Knobloch and Mai, 1986). With a total of 11 taxa from Rakowice Małe and seven from Żeliszów, these assemblages belong to the smallest mesofloras in Central Europe.

Sixteen taxa of mesofossils are described and figured in this paper: one species of megaspores, two species of conifer twigs, two conifer seeds, eight angiosperm reproductive structures, a single species of Costatheca (problematic, probably insect egg), and one type of insect coprolite. Additionally, there are two taxa Calathiocarpus octocostatus (Knobloch) Knobloch et Mai and
Walbeckia guttaeformis (Knobloch) Knobloch et Mai that should be mentioned: that material was not found in the collections, but was properly described and documented by Knobloch and Mai (1986); we, therefore, consider these two species to be part of the Lower Silesian Late Cretaceous mesoflora. Calathiocarpus is assigned to the Normapolles complex (Friis et al., 2011). The systematic position of genus Walbeckia was briefly discussed by Friis et al. (2006) as follows: the "fossil probably also belongs to Normapolles complex of plants based on close morphological and organisational similarity, however, so far no pollen has been observed." We agree in supposing that this taxon may be related to the Normapolles complex.

Sediments of the two localities, Rakowice Małe and Żeliszów, contain different mesofloras, and so represent rather different vegetation types:

- The Rakowice Małe mesoflora has a prevalence of fossil fruits of the Normapolles complex, representing alluvial plain and upland vegetation, similarly to the Turonian-Santonian flora from the South Bohemian Basins, described in detail by Knobloch and Mai (1986).

- The Żeliszów mesoflora is rich in conifer remains, representing swamp/wetland vegetation, with Geinitzia twigs and Seletya kristofovichii seeds, similarly to the Santonian mesoflora of Quedlinburg (Knobloch and Mai, 1986; Kunzmann, 1999).

The terrestrial flora, the source of the mesofossils described herein (Rakowice Małe assem- 

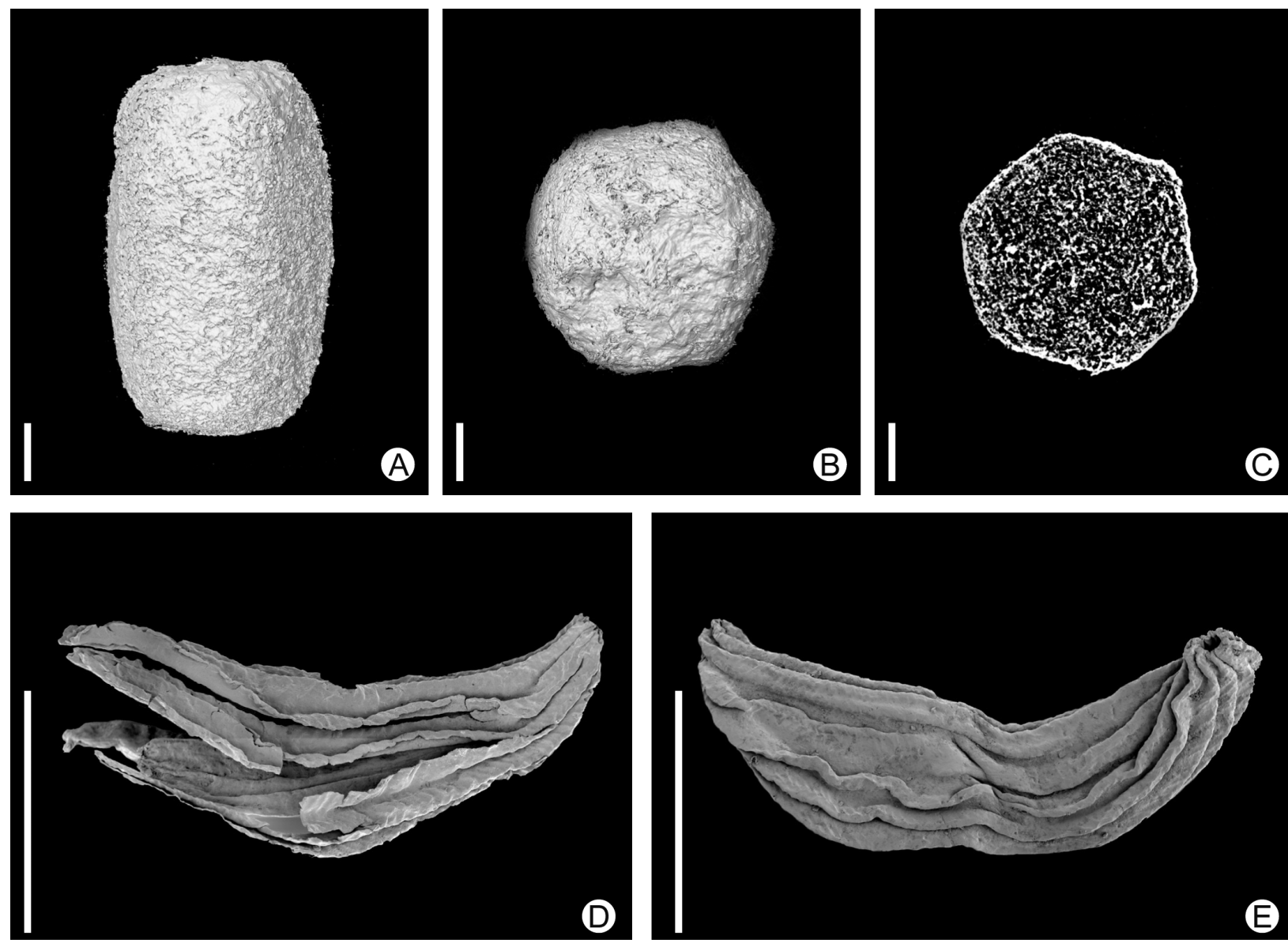

FIGURE 10. Insect remains (A) insect coprolite no. K2768 (A) coprolithes lateral view, no. K2768, scale bar $0.1 \mathrm{~mm}$, Rakowice Małe locality (B) coprolite apical view, hexagonal in outline, no. K2768, scale bar 0.1 mm, Rakowice Małe locality (C) X-ray image, cross section, no. K2768, scale bar $0.1 \mathrm{~mm}$, Rakowice Małe locality. (D) Costatheca striata no. K3010 scale bar $1 \mathrm{~mm}$, Żeliszów locality (E) Costatheca striata showing "operculum" no. K3011 scale bar $1 \mathrm{~mm}$. Żeliszów locality.

blage as well as Żeliszów mesoflora), grew on the East Sudetic Island, one of those forming the European Archipelago on the seaway between the Northern Ocean and the Tethys in the south (CsikiSava et al., 2015; Leszczyński, 2018). The Coniacian-Santonian vegetation of the East Sudetic Island, characterised on the basis of angiospermdominated mega- and mesofossil assemblages and of fern-dominated palynoassemblages (Halamski et al., 2020), consisted of several communities, among which back swamps and several variants of riparian forests are of interest herein as possible sources of mesofossils. Important megafossil taxa include the conifer Geinitzia, three species of the presumed basal eudicot Dewalquea, the fagalean Dryophyllum, and platanoids.

Halamski et al. (2020) distinguished eight Late Cretaceous megafloral assemblages in the North Sudetic Basin. The Assemblage 5 corresponds to the upper (coaly) portion of the Nowogrodziec Mb., which is the only part of the stratigraphic sequence that yielded any mesoflora. The upper portion of the Nowogrodziec Mb. has also yielded one of the two palynological assemblages studied by Halamski et al. (2020), termed Palynoassemblage A. However, plant megafossils from the Assemblage 5 are interpreted to have originated from a conifer swamp forest. The Normapolles mesofossils were produced by plants growing in communities more alike those recorded as megafossils in the slightly younger Assemblages 6 and 8 (Czerna Fm., unnamed member, lower-middle Santonian). The latter are interpreted as recording variants of riparian forests.

The Rakowice Małe mesoflora is similar to the South Bohemian flora in dominance of Normapolles complex. However, flowers and fruits of Normapolles complex are present in the South Bohemian flora in significantly greater amounts, both in terms of specimens and of taxa and other 
TABLE 1. List of the taxa found on the localites Rakowice Małe and Żeliszów.

\begin{tabular}{lccc}
\hline \multicolumn{1}{c}{ Taxon } & $\begin{array}{c}\text { Found at locality } \\
\text { Rakowice Małe in } \\
1986\end{array}$ & $\begin{array}{c}\text { Found at locality } \\
\text { Rakowice Małe in } \\
2017\end{array}$ & $\begin{array}{c}\text { Found at locality } \\
\text { Żeliszów in 2019 }\end{array}$ \\
\hline $\begin{array}{l}\text { Ricinospora sp. } \\
\text { Cunninghamites cf. squamosus }\end{array}$ & & $\mathrm{X}$ & $\mathrm{X}$ \\
Alapaja sp. & & $\mathrm{X}$ \\
Seletya sp. & & $\mathrm{X}$ \\
Geinitzia formosa Heer 1871 & $\mathrm{X}$ & $\mathrm{X}$ \\
Calathiocarpus octocostatus & $\mathrm{X}$ & \\
Caryanthus communis & $\mathrm{X}$ & \\
Caryanthus trebecensis & $\mathrm{X}$ & \\
Caryanthus triasseris & $\mathrm{X}$ & \\
Caryanthus sp. & $\mathrm{X}$ & \\
Walbeckia guttaeformis & $\mathrm{X}$ & \\
Zlivifructus vachae & $\mathrm{X}$ & \\
Zlivifructus microtriasseris & $\mathrm{X}$ & \\
Fruit of Normapolles affinity & & \\
Flower of Normapolles affinity & & \\
Staminate flower of Normapolles affinity & & \\
Insect coprolite & & \\
Costatheca striata & & & \\
\hline
\end{tabular}

angiosperm groups (platanoids, ericoids) also show high diversity there. The Rakowice Małe mesoflora is also similar to the Aachen Santonian mesoflora, with which it shares three genera: Caryanthus, Calathiocarpus, and Walbeckia (Knobloch and Mai, 1986). It also shares two genera, Caryanthus (C. triasseris) and Calathiocarpus, with the Santonian mesoflora of the German locality Walbeck from the foothills of the Vosges (Vogesen) mountains. There are additional minor findings of reproductive organs from Carpathian flysch sediments in southern Poland (Turonian - Santonian) that also show "Normapolles nuts" similar to those from Rakowice Małe, for example, Caryanthus communis and Caryanthus deltoides as well as insect eggs Knoblochia cretacea from Rabka Zaryte (Heřmanová et al., 2013). However, flysch sediments are sedimentologically different from the sediments bearing the flora of Rakowice Małe.

In the Nowogrodziec Member of the Czerna Formation in Lower Silesia, palynological studies by M. Svobodová and E. Durska in Halamski et al. (2020) showed that the palaeoassemblage was dominated by fern spores and pollen grains of the Normapolles type. Our current study confirms this work by documenting the presence of a certain number of angiosperms of various genera that may have produced such pollen.

\section{CONCLUSIONS}

Eighteen taxa of mesofossils are mentioned in this paper. One species of megaspore, two species of conifer twigs, two conifer seeds, 10 angiosperm reproductive structures related to the Normapolles complex, one species of Costatheca (problematic, probably insect egg), and one type of insect coprolite. The material investigated herein comes from two localities, Rakowice Małe and Żeliszów (Lower Silesia). The Rakowice Małe mesoflora has a prevalence of fruit fossils of the Normapolles complex, representing alluvial plain and upland vegetation. The Żeliszów mesoflora is rich in conifer remains, representing swamp/wetland vegetation, with Geinitzia twigs and Seletya kristofovichii seeds.

\section{ACKNOWLEDGMENTS}

Access to the quarries at Rakowice Małe and at Żeliszów was kindly authorised by A. Sroka (Kwarcyty Bolesławieckie S.A.). The field work was supported by assistance of P. Raczyński (University of Wrocław) and J. Váňa (National Museum Prague - NMP). Preparation of mesofossils was accomplished by J. Bubník (NMP) and J. Váňa (NMP). SEM studies were assisted by L. Váchová (NMP). Thanks to P. Daneš for English editing. 
Research was financed through the grant "The Late Cretaceous flowering plant expansion in the context of the transgression of the Central European Sea" (2016/21/B/NZ8/02443) of the National Science Centre, Poland to ATH, the
Czech Grant Agency (20-06134S), the Czech Ministry of Culture (IP DKRVO 2019-2023 2.I.b, National Museum, 00023272) and within institutional support RVO 67985831 of the Institute of Geology of the Czech Academy of Sciences.

\section{REFERENCES}

Bartling, F.G. 1830. Ordines naturales Plantarum eorumque characteres et affinitates, adjecta generum enumeratione, Gottingae.

Batten, D.J. 1981. Stratigraphic, palaeogeographic and evolutionary significance of Late Cretaceous and Early Tertiary Normapolles pollen. Review of Palaeobotany and Palynology, 35:125-137. https://doi.org/10.1016/0034-6667(81)90104-4

Batten, D.J. 1988. Revision of Dijkstra's Late Cretaceous megaspore and other plant microfossils from Limburg, The Netherlands. Mededelingen Rijks Geologische Dienst, 41:155.

Batten, D.J. and Christopher, R.A. 1981. Key to the recognition of Normapolles and some morphologically similar pollen genera. Review of Palaeobotany and Palynology, 35:359-383. https://doi.org/10.1016/0034-6667(81)90117-2

Batten, D.J. and Zavattieri, A.M. 1995. Occurrence of dispersed seed cuticles and similar microfossils in mainly Cretaceous successions of the Northern Hemisphere. Cretaceous Research, 16:73-94. https://doi.org/10.1006/cres.1995.1005

Batten, D.J. and Zavattieri, A.M. 1996. Re-examination of seed cuticles from Cretaceous deposits in West Greenland. Cretaceous Research, 17:691-714. https://doi.org/10.1006/cres.1996.0037

Bergad, R.D. 1978. Ultrastructural studies of selected North American Cretaceous Megaspores of Minerisporites, Erlansosporites, Horstisporites, and Ricinospora, n. gen. Palynology, 2:3951. https://doi.org/10.1080/01916122.1978.9989164

Berry, E.W. 1910. Contributions to the Mesozoic Flora of the Atlantic Coastal Plain-V. North Carolina. Bulletin of the Torrey Botanical Club, 37(4):181-200. https://doi.org/10.2307/2478947

Berry, E.W. 1925. The flora of the Ripley Formation. United States Geological Survey Professional Paper, 136:1-94. https://doi.org/10.3133/pp136

Binda, P.L. and Nambudiri, E.M.V. 1983. Fossil seed cuticles from the Upper Cretaceous Whitemud beds of Alberta and Saskatchewan Canada. Canadian Journal of Botany, 61:2717-2718. https://doi.org/10.1139/b83-299

Bosma, H.F., van Konijnenburg-van Cittert, J.H.A., van der Ham, R.W.J.M., van Amerom, H.W.J., and Hartkopf-Fröder, C. 2009. Conifers from the Santonian of Limburg, The Netherlands. Cretaceous Reschearch, 30:483-495. https://doi.org/10.1016/j.cretres.2008.09.007

Bosma, H.F., Kunzmann, L., Kvaček, J., and van Konijnenburg-van Cittert, J.H.A. 2012. Revision of the genus Cunninghamites (fossil conifers), with special reference to nomenclature, taxonomy and geological age. Review of Palaeobotany and Palynology, 182:20-31. https://doi.org/10.1016/j.revpalbo.2012.06.004

Bronn, H.G. 1835-37 [1834-38 (39?)]. Lethaea geognostica, oder Abbildungen und Beschreibungen der für die Gebirgs-Formationen bezeichnendsten Versteinerungen. Zweite Auflage. Erster Band, das Übergangs- bis Oolithen- Gebirge enthaltend. E. Schweitzerbart's Verlagshandlung, Stuttgart.

Cavalier-Smith, T. 1981. Eukaryote kingdoms: seven or nine? Biosystems, 14(3-4):461-481. https://doi.org/10.1016/0303-2647(81)90050-2

Cavalier-Smith, T. 1987. Eukaryotes with no mitochondria. Nature, 326 (6111):332-333. https://doi.org/10.1038/326332a0

Chatziemmanouil J.P. 1982. The Upper Cretaceous of the Vomb Trough, southern Sweden. Stockholm Contributions in Geology, 38:57-161. 
Colin, J.P., Néraudeau, D., Nel, A., and Perrichot, V. 2011. Termite coprolites (Insecta: Isoptera) from the Cretaceous of western France: a palaeoecological insight. Revue de Micropaléontologie, 54:129-139. https://doi.org/10.1016/j.revmic.2011.06.001

Csiki-Sava, Z., Buffetaut, E., Ösi, A., Pereda-Suberbiola, X., and Brusatte, S.L., 2015. Island life in the Cretaceous - faunal composition, biogeography, evolution, and extinction of land-living vertebrates on the Late Cretaceous European archipelago. Zookeys, 469:1-161. https://doi.org/10.3897/zookeys.469.8439

de Candolle, A.P. 1824. Prodromus systematis naturalis regni vegetabilis, sive, Enumeratio contracta ordinum generum specierumque plantarum huc usque cognitarium, juxta methodi naturalis, normas digesta. Parisiis: Sumptibus Sociorum Treuttel et Würtz. https://doi.org/10.5962/bhl.title.286

de Jussieu, A.L. 1789. Genera Plantarum, Secundum Ordines Naturales Disposita juxta Methodum in Horto Regio Parisiensi Exaratam. Herissant and Barrois, Paris. https://doi.org/10.5962/bhl.title.284

Dijkstra, S.J. 1949. Megaspores and some other fossils from the Aachenian (Senonian) in South Limburg, Netherlands. Mededelingen van de Geologische Stichting Nieuwe Serie, 3:19-33.

Dijkstra, S.J. 1959. On megaspores, Charophyta fruits and some other small fossils from the Cretaceous. Palaeobotanist, 8:8-18.

Doell, J.C. 1857. Flora des Grossherzogthums Baden. Erster Band. G. Braun'sche Hofbuchhandlung, Carlsruhe.

Dorofeev, P. J. 1979. O semenach mělovych chvojnych. Botaničeskij Žurnal, 3:305-317.

Engler, A. 1892. Syllabus der Vorlesungen über Specielle und Medicinisch-Pharmaceutische Botanik. Eine Uebersicht über das gesammte Pflanzensystem mit Berücksichtigung der Medicinal-und Nutzpflanzen. Gebrüder Borntraeger Verlag, Berlin. https://doi.org/10.5962/bhl.title.69853

Enlicher, S. 1847. Synopsis Coniferarum Fossilium. Sangalli, Apud Scheitlin and Zollikofer. https://doi.org/10.5962/bhl.title.127447

Friis, E.M. 1983. Upper Cretaceous (Senonian) floral structures of juglandalean affinity containing Normapolles pollen. Review of Palaeobotany and Palynology, 39:161-188. https://doi.org/10.1016/0034-6667(83)90015-5

Friis, E.M., Crane, P., and Pedersen, K.R. 2011. Early Flowers and Angiosperm Evolution. Cambridge University Press. https://doi.org/10.1017/CBO9780511980206

Friis, E.M., Pedersen, K.R., and Schönenberger, J. 2003. Endressianthus, a new Normapolles producing plant genus of fagalean affinity from the Late Cretaceous of Portugal. International Journal of Plant Sciences, 164:S201-S223. https://doi.org/10.1086/376875

Friis, E.M., Pedersen, K.R., and Schönenberger, J. 2006. Normapolles plants: a prominent component of the Cretaceous rosid diversification. Plant Systematics and Evolution, 260:107-140. https://doi.org/10.1007/s00606-006-0440-y

Frumina, S.I., Zhilin, S.G., and Korchagina, I.A., 1995. Alapaja (Taxodiaceae) seeds from the Cenomanian-Turonian of northern Kazakhstan. Paleontological Journal, 29:194-202.

Geinitz, H.B. 1842. Characteristik der Schichten und Petrefacten des Sächsisch-Böhmischen Kreidegebirges. Arnoldische Buchhandlung, Dresden-Leipzig, Germany.

Góczán, F., Groot, J., Krutzsch, W., and Pacltová, B. 1967. Die Gattungen des "Stemma Normapolles Pflug 1953b" (Angiospermae) - Neubeschreibungen und Revision europaïscher Formen (Oberkreide bis Eozän). Paläontologische Abhandlungen B, 2(3):427633.

Gorozhankin, I.N. 1904. Lektsii po Morfologii i Sistematike Archegonialnyh Rastenij. II, Pteridophyta, I, Archispermae. Mamontov, Moskva.

Gray, S.F. 1821. A Natural Arrangement of British Plants. Baldwin, Cradock and Joy, London.

Halamski, A.T., Kvaček, J., and Vajda, V. 2016. Late Cretaceous (Campanian) leaf and palynoflora from southern Skåne, Sweden, p. 434:207-229. In Kear, B.P., Lindgren, J., Hurum, J. H., Milàn, J., and Vajda, V. (eds.), Mesozoic Biotas of Scandinavia and its Arctic Territories. Geological Society, London, Special Publications. https://doi.org/10.1144/ SP434.16

Halamski, A.T., Kvaček, J., Heřmanová, Z., Durska, E., Svobodová, M., and Raczyński, P. 2018. Nowe dane o makro-, mezo- i mikroflorze późnokredowej Niecki Północnosudeckiej, p. 2223. In Skrzyński, G., Badura, M., and Noryśkiewicz, A.M. (eds.), Sympozjum Sekcji Paleobotanicznej Polskiego Towarzystwa Botanicznego. Polska Akademia Nauk, Muzeum Ziemi w Warszawie, Warszawa. 
Halamski, A.T., Kvaček, J., Svobodová, M., Durska, E., and Heřmanová, Z. 2020. Late Cretaceous mega-, meso-, and microfloras from Lower Silesia. Acta Palaeontologica Polonica, 65(4): 811-878. https://doi.org/10.4202/app.00744.2020

Hall, J.W. 1967. Invalidity of the name Chrysotheca Miner for microfossils. Journal of Paleontology, 41:1298-1299.

Harris, T.M. 1969. Naming a fossil conifer, p. 243-252. In Santarau, H. (ed.), J. Sen Memorial Volume, Botanical Society of Bengal, Calcutta.

Harris, T.M., Miller, J., and Millington, W. 1979. The Yorkshire Jurassic Flora. V. Coniferales. British Museum (Natural History), London, UK. https://doi.org/10.5962/bhl.title.118957

Heer, O. 1871. Beiträge zur Kreideflora II. Zur Kreideflora von Quedlinburg. Neue Denkschriften der Allg. Schweizerischen Gesellschaft für die gesammten Naturwissenschaften, 24:1-15.

Heřmanová, Z. and Kvaček, J. 2012. New record of genus Caryanthus from the Cretaceous of South Bohemia (Czech Republic). Sborník Národního Muzea v Praze, řada B - př́rodní vědy, 68:47-50.

Heřmanová, Z., Bodor, E.R., and Kvaček, J. 2013. Knoblochia cretacea, Late Cretaceous insect eggs from Central Europe. Cretaceous Research, 45:7-15. https://doi.org/10.1016/j.cretres.2013.07.001

Heřmanová, Z., Kvaček, J., and Dašková, J. 2016. Caryanthus diversity in the Late Cretaceous. Review of Palaeobotany and Palynology, 23:33-47. https://doi.org/10.1016/j.revpalbo.2016.04.012

Heřmanová, Z., Dašková, J., Ekrt, B., and Kvaček, J. 2017. Zlivifructus gen. nov., a new member of the Normapolles complex. Review of Palaeobotany and Palynology, 246:177-184. https://doi.org/10.1016/j.revpalbo.2017.06.012

Heřmanová, Z., Kvaček, J., Halamski, A.T., Zahajská, P., and Šilar, J. 2019. Reinterpretation of fossil reproductive structures Zlivifructus microtriasseris (Normapolles complex, Fagales) from the Czech and Polish Late Cretaceous. Review of Palaeobotany and Palynology, 268:88-94. https://doi.org/10.1016/j.revpalbo.2019.06.013

Hollick, A. and Jeffrey, E.C. 1909. Studies of Cretaceous coniferous remains from Kreischerville, New York. Memoirs of the New York Botanical Garden, 3:1-137. https://doi.org/10.5962/bhl.title.44790

Hosius, A. and von der Marck, W. 1880. Die Flora der westfälischen Kreideformation. Palaeontographica, 26:125-236.

Janetschke, N. and Wilmsen, M. 2014. Sequence stratigraphy of the lower Upper Cretaceous Elbtal Group (Cenomanian-Turonian of Saxony, Germany). Zeitschrift der Deutschen Gesellschaft für Geowissenschaften, 165:179-208. https://doi.org/10.1127/1860-1804/2013/0036

Knobloch, E. 1964. Neue Pflanzenfunde aus dem südböhemischen Senon. Jahrbuch des Staatlichen Museums für Mineralogie und Geologie zu Dresden 1964:133-201.

Knobloch, E. 1970. Ermöglicht die Paläokarpologie Aussagen zur Genese und Biostratigraphie der jungen Flyschsedimente? Mitteilungen der Bayerischen Staatssammlung für Paläontologie und Historische Geologie, 10:297-308.

Knobloch, E. 1971. Fossile Früchte und Samen aus der Flyschzone der mährischen Karpathen. Sborník Geologických věd Paleontologie, 13:7-43.

Knobloch, E. 1977. Paläokarpologische Charakteristik der Flyschzone der mährischen Karpaten. Sborník Geologických věd Paleontologie, 19:79-135.

Knobloch, E. 1981. Die Gattung Costatheca Hall in der mitteleuropäischen Kreide. Sborník Geologických věd Paleontologie, 24:95-115.

Knobloch, E. 1984. Megasporen aus der Kreide von Mitteleuropa. Sborník Geologických věd Paleontologie, 26:157-195.

Knobloch, E. and Mai, D.H. 1983. Carbonized seeds and fruits from the Cretaceous of Bohemia and Moravia and their stratigraphical significance. Knihovnička zemního plynu a nafty, 4:305332.

Knobloch, E. and Mai, D.H. 1986. Monographie der Früchte und Samen in der Kreide von Mitteleuropa. Rozpravy Ústředního ústavu geologického, 47:1-219.

Knowlton, F.H. 1905. Fossil plants of the Judith River beds. U.S. Geological Survey Bulletin, 257:129-155.

Korall, P. and Taylor W.A. 2006. Megaspore morphology in the Selaginellaceae in a phylogenetic context: a study of the megaspore surface and wall structure using scanning electron microscopy. Grana, 45:22-60. https://doi.org/10.1080/00173130500520453 
Kovach, W.L. and Dilcher, D.L. 1988. Megaspores and other dispersed plant remains from the Dakota Formation (Cenomanian) of Kansas, U. S. A. Palaeontology, 12:89-119. https://doi.org/10.1080/01916122.1988.9989338

Kräusel, R. 1922. Beiträge zur Kenntniss der Kreideflora. I. Über einige Kreidepflanzen von Swalmen (Niederlande). Mededeelingen van's Rijks Geologischen Dienst, 2:1-40.

Kunzmann, L. 1999. Koniferen der Oberkreide und ihre Relikte im Tertär Europas. Abhandlungen des Staatlichen Museums für Mineralogie und Geologie zu Dresden, 45:1191.

Kunzmann, L., Knoll, H., and Gaipl, R. 2003. Neue Untersuchungen an Geinitzia Endl. 1847 aus den Aachener Schichten von Belgien und Deutschland (Oberes Santon, Oberkreide). Feddes Repertorium, 114(1-2):1-24. https://doi.org/10.1002/fedr.200390014

Kunzmann, L. and Friis, E. M. 1999. Zum Vorkommen von Koniferensamen mit stark gekrümmten Keimfächern in der Oberkreide. Feddes Repertorium, 110(5-6):341-347.

Kvaček, J. 2013. Fricia nobilis from the Turonian of the Czech Republic reinterpreted as an ovuliferous cone of a cupressoid conifer. Sborník Národního Muzea v Praze, řada B přírodní vědy, 69:123-128.

Leszczyński, S. 2010. Coniacian-?Santonian paralic sedimentation in the Rakowice Małe area of the North Sudetic Basin, SW Poland: sedimentary facies, ichnological record and palaeogeographical reconstruction of an evolving marine embayment. Annales Societatis Geologorum Poloniae, 80:1-24.

Leszczyński, S. 2018. Integrated sedimentological and ichnological study of the Coniacian sedimentation in North Sudetic Basin, SW Poland. Geological Quarterly, 62:7670816. https://doi.org/10.7306/gq.1440

Li, W., Batten, D.J., Zhang, D., and Zhang, L. 1987. Early Cretaceous megaspores from the Jalainor Group of northeast Inner Mongolia, P.R. China. Palaeontographica B, 206:117-135.

Lindley, J. 1830 An Introduction to the Natural History of Botany. Longman, Rees, Orme, Brown, and Green, London.

Linné, C. 1753. Species Plantarum: exhibentes Plantas rite cognitas, ad Genera relatas, cum differentiis specificis, nominibus trivialibus, synonymis selectis, locis natalibus, secundum systema sexuale digestas. Tomus I [II]. Impensis Laurentii Salvii, Holmiae. https://doi.org/10.5962/bhl.title.669

Lupia, R. 2015. Mid-Cretaceous megaspore floras from Maryland, USA. Journal of Paleontology, 83:494-521. https://doi.org/10.1017/jpa.2015.21

Milewicz, J. 1997. Upper Cretaceous of the North Sudetic Depression (litho- and biostratigraphy, paleogeography, tectonics and remarks on raw materials). Acta Universitatis Wratislaviensis, Prace Geologiczno-Mineralogiczne 61: 5-59.

Miner, E.L. 1935. Paleobotanical examinations of Cretaceous and Tertiary coals. American Midland Naturalist, 16:585-625. https://doi.org/10.2307/2419854

Mitura, J., Cieśliński, S., and Milewicz, J. 1969. Inoceramy górnokredowe z niecki północnosudeckiej. Biuletyn Państwowego Instytutu Geologicznego, 217:169-177.

Pacltová, B. 1981. The evolution and distribution of Normapolles pollen during the Cenophytic. Review of Palaeobotany and Palynology, 35:175-208. https://doi.org/10.1016/0034-6667(81)90108-1

Pflug, H.D. 1953. Zur Entstehung und Entwicklung des angiospermiden Pollen in der Erdgeschichte. Palaeontographica, 95:60-171.

Polette, F. and Batten, D.J. 2017. Fundamental reassessment of the taxonomy of five Normapolles pollen genera. Review of Palaeobotany and Palynology, 243:47-91. https://doi.org/10.1016/j.revpalbo.2017.04.001

Potonié R. 1956/9: Synopsis der Gattungen der Sporae dispersae I. Teil. Beihefte zum Geologischen Jahrbuch, 23:1-103.

Prantl, K. 1874. Lehrbuch der Botanik für Mittelschulen. W. Engelmann, Leipzig.

Rüffle, L. and Trostheide, F. 2000. Ergänzungen zur Oberkreide-Flora von Quedlinburg (Deutschland) und einiger weiterer Kreide-Fundstätten (geographische Beziehungen). Feddes Repertorium, 111(7-8):433-444.

Schönenberger, J., Pedersen, K.R., and Friis, E.M. 2001. Normapolles flowers of fagalean affinity from the Late Cretaceous of Portugal. Plant Systematics and Evolution, 226:205-230. https://doi.org/10.1007/s006060170066

Seward, A.C. 1919. Fossil Plants; A Text Book for Students of Botany and Geology. Cambridge University Press, Cambridge. 
Sims, H.J., Herendeen, P.S., Lupia, R., Christopher, R.A., and Crane, P. 1999. Fossil flowers with Normapolles pollen from the Upper Cretaceous of southeastern North America. Review of Palaeobotany and Palynology, 106:131-151. https://doi.org/10.1016/S0034-6667(99)00008-1

Singh, C. 1983. Cenomanian microfloras of the Peace River area, northwestern Alberta. Bulletin - Alberta Research Council, 44:1-322.

Sternberg, K.M. 1838. Versuch einer geognostisch-botanischen Darstellung der Flora der Vorwelt. Gotlieb Haase Söhne, Prag.

Tiffney, B.H. 1983. Possible confusion of small-sized seeds and insect eggs. International Association Palaeobotany Newsletter, 8:10-12.

Vangerow, E.F. 1954. Megasporen und andere pflanzliche Mikrofossilien aus der Aachener Kreide. Palaeontografica B, 96:24-38.

Walaszczyk, I. 2008. North Sudetic Basin (Outer Sudetic Cretaceous), p. 959-960. In McCann, T. (ed.), The Geology of Central Europe. Volume 2: Mesozoic and Cenozoic. https://doi.org/ 10.1144/CEV2P

Voigt, S., Wagreich, M., Surlyk, F., Walaszczyk, I., Uličný, D., Čech, S., Voigt, T., Wiese, F., Wilmsen, M., Niebuhr, B., Reich, M., Funk, H., Michalík, J., Jagt, J.W.M., Felder, P.J., and Schulp, A.S. 2008. Cretaceous, p. 923-997. In McCann, T. (ed.), The Geology of Central Europe. Volume 2: Mesozoic and Cenozoic. The Geological Society, London.

von Gaertner, H.-R. and Walther, H.W. (coord.) 1971. International Geological Map of Europe and the Mediterranean Region 1: 5000 000. International Geological Congress, Commission for the Geological Map of the World, Bundesanstalt für Bodenforschung and UNESCO.

von Siebold C.T. 1848. Lehrbuch der vergleichenden Anatomie der Wirbellosen Thiere. Erster Theil, p. XIV, 679. In von Siebold, C.T. and Stannius, H. (eds.), Lehrbuch der vergleichenden Anatomie. - Verlag von Veit and Comp., Berlin. https://doi.org/10.5962/bhl.title.10707

Zijlstra, G., van Konijnenburg-van Cittert, J.H.A., Kunzmann, L., Bosma, H., and Kvaček, J. 2010. Proposal to conserve the name Geinitzia with a conserved type (fossil Coniferophyta). Taxon, 59:301. https://doi.org/10.1002/tax.591037

Zimmermann, W. 1959. Die Phylogenie der Pflanzen, Gustav Fischer Verlag. 